\title{
Late Quaternary sedimentation and the postglacial sea-level minimum in Port au Port Bay and vicinity, west Newfoundland
}

\author{
D.L. Forbes, J. Shaw \\ Geological Survey of Canada, Atlantic Geoscience Centre, Bedford Institute of Oceanography, \\ P.O. Box 1006, Dartmouth, Nova Scotia B2Y 4A2, Canada \\ and \\ B.G. Eddy \\ Earth and Ocean Research Limited, 22 Waddell Avenue, Dartmouth, Nova Scotia B3B 1K3, Canada
}

Dale Received January 7, 1992

Date Accepted March 15, 1993

\begin{abstract}
Marine geophysical surveys in Port au Port Bay, west Newfoundland, have revealed more than $50 \mathrm{~m}$ of Quatemary fill in East Bay and lesser amounts in other basins. Six seismostratigraphic units have been identified and interpreted as follows: (1) an acoustically unstratified unit, including till and other ice-contact deposits, representing the products of deposition or loading by grounded glacial ice or of other ice-contact processes; (2) a crudely stratified unit, believed to be mainly ice-contact or ice-proximal sand and gravel; (3) a conformably stratified unit, interpreted as glacimarine and early paraglacial sandy silt and clay; (4) a weakly-stratified to acoustically transparent unit consisting of postglacial mud; (5) a wedge-shaped unit dominated by clinoform reflections, representing postglacial deltaic sand and gravel in submerged terraces off Fox Island River; and (6) thin wedges of acoustically stratified deposits, considered to represent transgressive shoreface, late-delta, and tidal units of sand and gravel. Radiocarbon determinations on paired bivalves from unit 3 indicate a range of ages from $>13.3$ to $<10.8 \mathrm{ka}$, implying initally rapid late- and postglacial sedimentation. Paraglacial sediment supply from small glaciated river basins is known to be maximized during and shortly after deglaciation and to decrease rapidly thereafter. This is consistent with an interpretation involving rapid early development of the subaerial fan and submerged delta terraces of Fox Island River. Sediment derived from the river and from coastal erosion along the front of the fan has been transported southward under net longshore drift to sinks in the vicinity of Two Guts Pond. The submerged delta terraces and erosional shore platforms in Port au Port Bay and St. George's Bay indicate that the postglacial sea-level minimum in this area was approximately $25 \mathrm{~m}$ below present. These features are undated but their age is estimated to be about $9.5 \pm 1 \mathrm{ka}$.
\end{abstract}

Des levés géophysiques marins dans la baie de Port au Port, dans l'ouest de Terre-Neuve, ont montré la présence de plus de $50 \mathrm{~m}$ de dépôts quaternaires dans la baie East et des quantités moindres dans les autres bassins. Six unités sismostratigraphiques ont été identifiées et interprétées comme suit: (1) une unité acoustiquement non stratifiée, incluant du till et d'autres dépôts de contact de glace, qui représentent les produits du dépôt ou du chargement par de la glace échouée ou par d'autres processus de contact de glace; (2) une unité grossièrement stratifiée, considérée comme étant principalement des sables et des graviers de contact de glace ou à proximité de la glace; (3) une unité conformément stratifiée, interprétée comme de l'argile et du silt sablonneux glacio-marins et paraglaciaires précoces; (4) une unité faiblement stratifiée à acoustiquement transparente consistant en boue postglaciaire; (5) une unité en biseau dominée par des réflections inclinées, représentant du sable et du gravier de delta postglaciaires dans des terrasses submergées au large de la rivière de Fox Island; et (6) des biseaux minces de dépôts acoustiquement stratifiés, considérés comme représentant des unités de sable et gravier transgressifs d'avant-plage, de delta tardives et tidales. Des datations au carbone sur des bivalves entiers de l'unité 3 indiquent un intervalle d'âge allant de $>13.3$ à $<10.8 \mathrm{ka}$, impliquant une sédimentation tardi- et post-glaciaire initialement rapide. L'afflux de sédiments paraglaciaires provenant de petits bassins de rivières affectés par les glaciers est reconnu être maximal pendant et peu après la déglaciation et décroître rapidement par la suite. Ceci est en accord avec une interprétation impliquant un développement précoce rapide du cône subaérien et des terrasses de delta submergées de la rivière de Fox Island. Les sédiments dérivés de la rivière et de l'érosion côtière le long de la partie frontale du cône ont été transportés vers le sud sous l'effet de courants côtiers à des trappes dans les alentours de l'étang de Two Guts. Les terrasses de delta submergées et les plates-formes côtières érosionnelles dans la baie de Port au Port et la Baie St.-George indiquent que le niveau postglaciaire minimal de la mer dans cette région était approximativement $25 \mathrm{~m}$ sous le niveau actuel. Ces modelés ne sont pas datés mais leur âge est estimé à environ $9.5 \pm 1 \mathrm{ka}$.

[Traduit par la rédaction]

Geological Survey of Canada Contribution No. 42991 


\section{INTRODUCTION}

As part of a regional mapping initiative in coastal waters of southeastern Canada during the late 1980s, the Geological Survey of Canada conducted marine surveys in Port au Port Bay and St. George's Bay on the west coast of Newfoundland (Fig. 1). Despite prior work on surficial sediments in Port au Port Bay by Shearer (1970) and Hill and Ruest (1980), no shallow seismic or sidescan sonar data were available prior to our work there. Furthermore, the bathymetry of Port au Port Bay was known only from 1890s British Admiralty charts with a limited number of spot soundings and some positioning errors. The principal objectives of our 1988 program were therefore to obtain high-resolution bottom and sub-bottom acoustic profiles, sidescan sonar imagery, and samples of the Quaternary sediment fill for the following purposes:

(1) to supplement the land record of the history of Quaternary glaciation and sea-level change in the area; in particular to determine the postglacial sea level minimum, which had been a matter of conjecture (e.g., Brookes et al., 1985; Grant, 1987);

(2) to obtain additional bathymetric data and acquire information on the thickness and stratigraphy of Quaternary sediments in the bay, adding to the earlier studies of surficial marine sediments (in particular the work of Shearer, 1970); (3) to evaluate patterns of sediment dispersal from Fox Island River, with particular reference to chromite placer genesis in East Bay.

The study was undertaken in part to provide a sedimentary context for the assessment of these placer deposits (EmoryMoore et al., 1992). Chromite is introduced via Fox Island River from sources in the Lewis Hills massif of the Bay of Islands ophiolite complex (Dunsworth et al., 1986; EmoryMoore et al., 1989; Corney, 1992). Anomalous chromite concentrations up to $5540 \mathrm{ppm}$ were found in samples and cores obtained during the 1988 survey (S winden and Forbes, 1989), whereas concentrations as high as $65,000 \mathrm{ppm}$ have been reported from beach deposits in the bay (Emory-Moore et al., 1988).

Early interest in postglacial sea-level changes along the southern west coast of Newfoundland arose from attempts to determine the limits of Labrador-centred glaciation and the relative importance of an independent Newfoundland ice cap during Late Wisconsinan time (Fairchild, 1918; Daly, 1921; Coleman, 1926; Flint, 1940; MacClintock and Twenhofel, 1940; Brookes, 1970, 1982). The region has continued to be a focus of surficial geological studies since the mid 1960s (e.g., Shearer, 1970, 1973; Grant, 1977, 1980, 1987, 1989a, 1991; Brookes, 1969, 1974, 1977a, 1977b, 1987; Brookes et al., 1985; Josenhans et al., 1990). Relative sea-level data from the area were used by Quinlan and Beaumont (1981, 1982) to constrain models of Late Wisconsinan ice loading and crustal response in eastern Canada. Later work on the structure, evolution, and stability of coastal sediment bodies (Forbes, 1984; Shaw and Forbes, 1987, 1992; Forbes et al., 1989; Shaw et al., 1990) has focused attention on late Holocene and present trends of relative sea level in the area.
The purpose of this paper is to bring together the results of the Port au Port Bay surveys, including new information on lithostratigraphy and radiocarbon chronology from a number of short gravity cores in the bay and a coastal peat section at Two Guts Pond (Fig. 2). In addition, we present evidence from both Port au Port Bay and nearby St. George's Bay for a postglacial lowstand of sea level at about $-25 \mathrm{~m}$, alluded to but not fully substantiated in previous publications (Forbes and Shaw, 1989; Shaw and Forbes, 1990a, 1990b). Finally, with respect to placer chromite genesis, we consider the implications of water-level fluctuations in relation to the timing of a probable early Holocene maximum in sediment supply from Fox Island River (cf. Church and Ryder, 1972; Church and Slaymaker, 1989).

\section{The Study Area}

\section{Coastal setting}

\section{Port au Port Bay}

Port au Port Bay is a small coastal embayment with an area of about $500 \mathrm{~km}^{2}$. It lies on the west coast of Newfoundland between Bay of Islands and St. George's Bay (Fig. 1). Port au Port Bay includes a number of elongated basins, aligned roughly parallel to the Long Point peninsula (Fig. 2). These basins have present maximum depths ranging from about $24 \mathrm{~m}$ in West Bay to more than $60 \mathrm{~m}$ in East Bay and approximately $45 \mathrm{~m}$ in the two basins north of Fox Island. The two northern basins were informally named "Fox" and "Serpentine" by Shearer (1970). Sill depths range from about 14 $\mathrm{m}$ for West Bay to $26 \mathrm{~m}$ for East Bay and 35 to $37 \mathrm{~m}$ for the two basins farther north. The shallower West Bay contains three separate closed depressions with depths greater than 20 $\mathrm{m}$. The two deepest depressions on the east side of Port au Port Bay (East Bay and "Fox Basin") contain thick deposits of acoustically stratified fine-grained sediments overlying a variable thickness of acoustically unstratified or irregularly stratified material (Forbes and Shaw, 1989; Eddy, 1989). Submerged deltaic terraces off Fox Island River constitute part of the evidence for lower relative sea levels and are described in more detail below.

Cliffs cut either in bedrock or in raised postglacial marine or fluvial deposits form much of the coastline of Port au Port Bay. The east coast north of Fox Island River is dominated by the high rock cliffs of Bluff Head. Lower rock cliffs are present along the south shore of East Bay, on parts of Shoal Point, locally in West Bay and on the Long Point peninsula. Raised deltaic terrace gravels feeding the tombolo at Port au Port (Flint, 1940) form prominent bluffs. Cliff-base and pocket beaches, some sandy and some gravel-dominated, are found in southern East Bay and along the Long Point peninsula. The southwestern shore of West Bay forms an extensive swash-aligned beach facing the long axis of the bay. A less extensive beach and small barrier complex occurs at the head of Piccadilly Bay in the southern extremity of West Bay. The other important beach system in Port au Port 


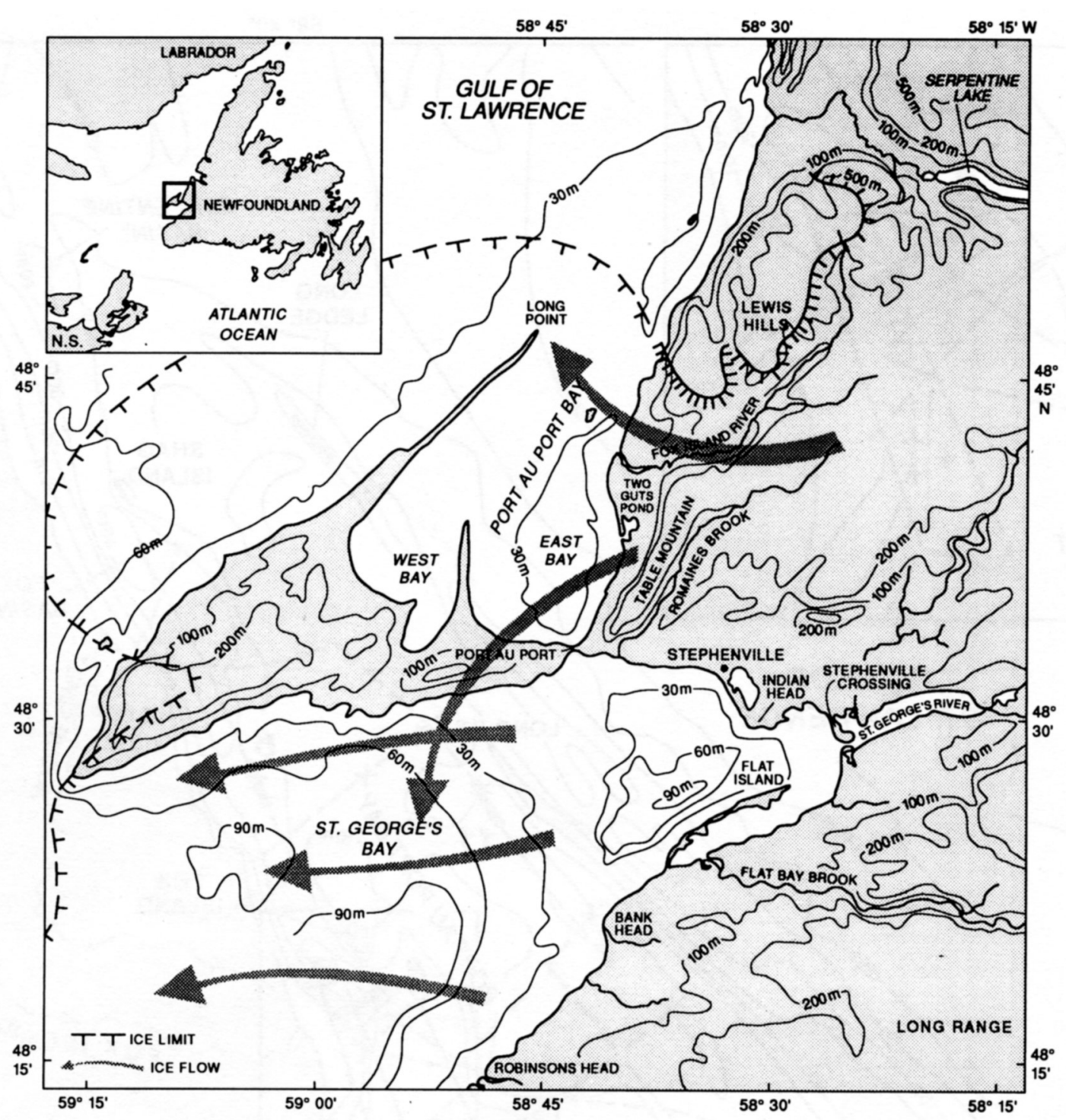

Fig. 1. Port au Port Bay and St. George's Bay, showing present coastline, bathymetry, and topography, with place names referred to in the text. Limits of Late Wisconsinan glaciation from Grant (1987). Inset: location on west coast of Newfoundland.

Bay extends from Fox Island River south to Two Guts Pond (Fig. 3). This drift-aligned beach, which contains high concentrations of placer chromite, is fed by sediment discharge from the river and by erosion of low cliffs developed along the margin of the early Holocene fan. The low sandy barrier at Two Guts Pond is so named because of the former existence of two tidal inlets. The area of the northern inlet is now occupied by broad washover flats and tidal exchange is limited to the southern channel.

The configuration of Port au Port Bay and the prevailing wind regime produce a restricted wave climate, with the most energetic waves approaching from a narrow fetch window to the north and northwest. This results in net southerly longshore currents and sediment transport along the east side of East Bay from Fox Island River south. Local waves generated within the bay are of lesser importance, although the southwestern shore of West Bay is exposed to a fetch of about 50 $\mathrm{km}$ to the north-northeast. The directions of net littoral transport in the southern parts of East and West bays, and along the Shoal Point peninsula between them, are more variable, resulting from the interaction of waves, tidal currents, and other wind-and circulation-driven surface currents (Shearer, 1970).

\section{St. George's Bay}

St. George's Bay is a funnel-shaped embayment on the south side of the Port au Port Peninsula (Fig. 1). It opens to the southwest and widens from about $4 \mathrm{~km}$ at the head of the bay to approximately $40 \mathrm{~km}$ opposite the end of the perinsula. A shallow sill extends across the bay from the Port au Port isthmus to Bank Head (Fig. 1) enclosing two basins with maximum depths of 57 and $97 \mathrm{~m}$. These basins occupy partially buried bedrock valleys more than $180 \mathrm{~m}$ deep that extend beneath the bayhead barriers at Stephenville and Stephenville Crossing (Shaw and Forbes, 1990b). A thick 


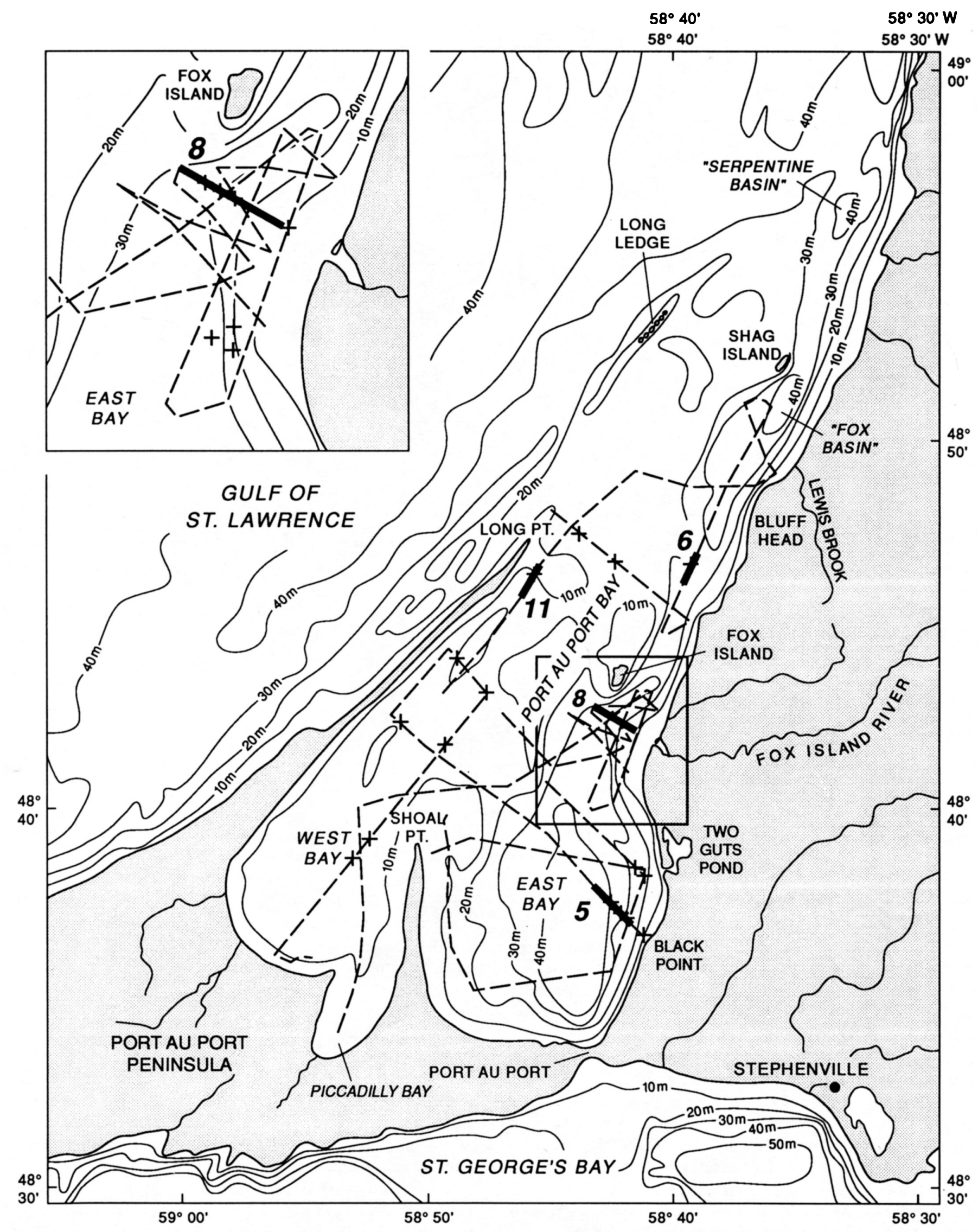

Fig. 2. Bathymetry and 1988 survey tracks, Port au Port Bay. Also shown are grab sample and core locations ( + ) and profile segments illustrated in Figures 5, 6, 8 and 11 . 


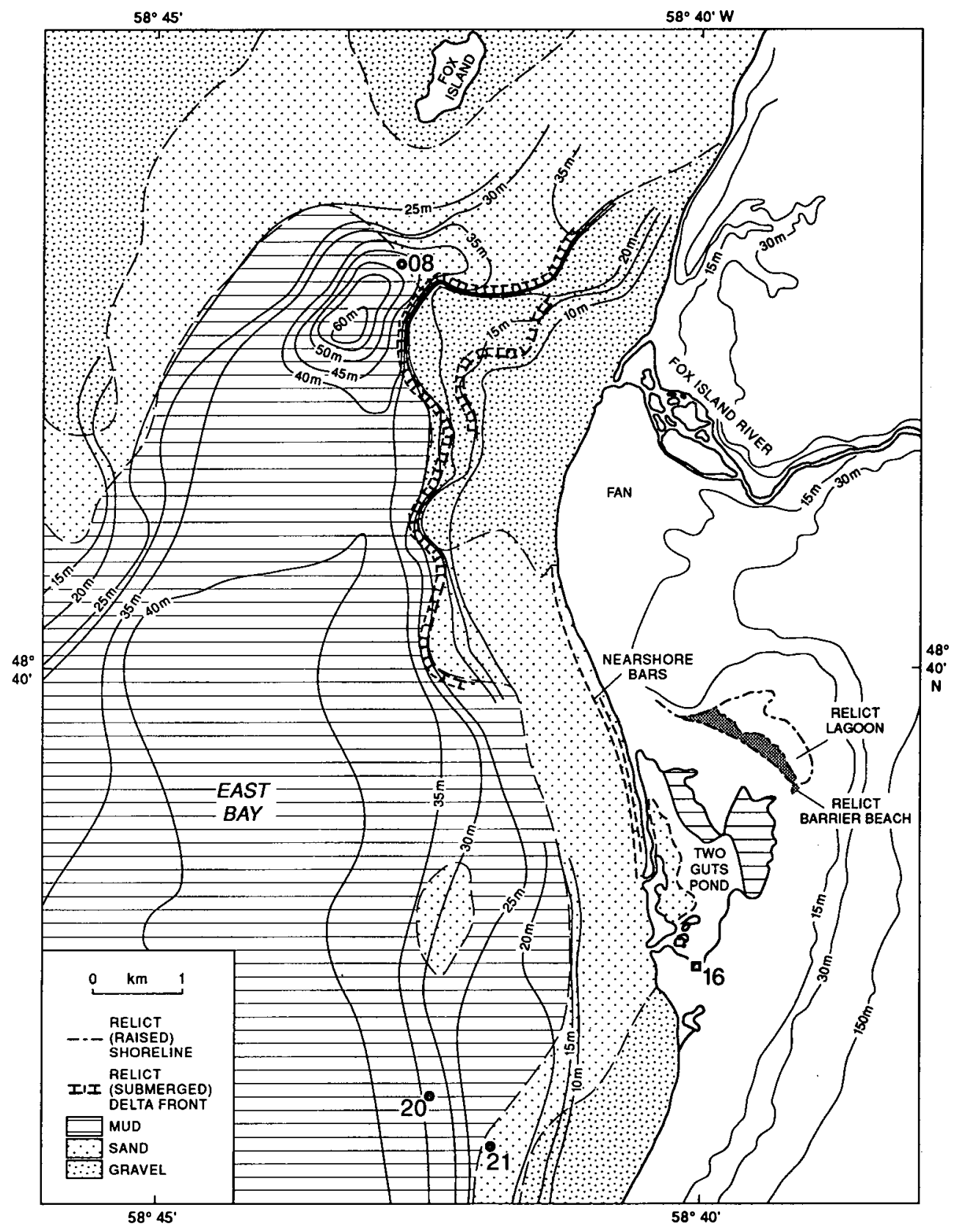

Fig. 3. Bathymetry and bottom types in the vicinity of Fox Island River and Two Guts Pond, showing complex morphology of submerged delta terraces, deep basin seaward of delta, and mounded Holocene muds on basin flank opposite. Also shown are the locations of cores 8, 20, and 21 and the peat section (16) at Two Guts Pond, low ridge interpreted as a raised barrier beach north of Two Guts, present beach and nearshore bars acting as a littoral transport corridor south around the Fox Island River fan, and barrier and backbarrier (washover and flood-delta) deposits at Two Guts Pond.

sequence of stratified Quaternary deposits occupies the bedrock valleys and other parts of the inner basins, while stacked units of acoustically unstratified (presumably ice-contact) deposits at least $85 \mathrm{~m}$ thick underlie parts of the sill (Shaw and Forbes, 1990b).

Because of the close proximity of Port au Port Bay and St. George's Bay, the former connection between them under higher relative sea levels as Late Wisconsinan ice withdrew from the area, and postulated links between ice withdrawal in St. George's Bay and late ice dynamics in the Port au Port area (cf. Grant in Blake, 1988), the history of Port au Port Bay is intimately linked to that of its southern neighbour. In addition, evidence for the sea-level lowstand in St. George's Bay forms an integral part of this study. Lowstand deltas have been identified at three locations around the bay (Shaw and Forbes, 1990b, 1992). As demonstrated later in this paper, the origin of the sediments underlying the southern end of the St. George's Bay sill is central to our interpretation of the Holocene lowstand position. 


\section{Regional geology}

\section{Bedrock}

Port au Port Bay occupies a structurally-controlled bedrock depression between the Port au Port Peninsula on the south, Long Point on the west, and the high ground of Table Mountain and the Lewis Hills on the east. The Lewis Hills massif consists primarily of Paleozoic ophiolites of the Humber Arm Allochthon (Williams and Cawood, 1989). Intermediate and lower structural slices of volcanic and sedimentary rocks form much of the relatively low-relief southern coast of the bay. Much of the Port au Port Peninsula to the south and the Table Mountain Anticline to the east consist of carbonate rocks of the Cambrian-Ordovician St. George and Port au Port groups and the Ordovician Mainland Sandstone, some of which have recently been reinterpreted as substantially allochthonous (Stockmal and Waldron, 1992). Structural alignment and faulting within these rocks define the general form of Port au Port Bay. The narrow spike of Long Point results from the erosional resistance of Ordovician sediments of the Long Point Group. Shoal Point, a conspicuous linear feature projecting into the southern part of Port au Port Bay between East and West bays, is believed to be a rock-cored ridge that extends north below present sea level toward Fox Island (Figs. 2, 4). South of the Port au Port Peninsula, St. George's Bay (Fig. 1) forms part of a broad depression, the St. George's Bay lowland, reflecting the distribution of less resistant Carboniferous sedimentary rocks of the Codroy and Barachois groups. These are downfaulted against crystalline rocks of the Lewis Hills to the north, the small Indian Head inlier in the middle, and the Long Range highlands to the southeast (Riley, 1962; Williams, 1985).

\section{Surficial deposits}

Quaternary sediments onshore in the Port au Port and St. George's Bay region record the presence and retreat of Late Wisconsinan glacial ice and changes in relative sea level. The oldest unit is a compact lodgement till, the St. George's River Drift (MacClintock and Twenhofel, 1940), overlain by deposits of the Bay St. George Delta. These consist of bottomset muds and foreset to topset sands and gravels, recording marine submergence as ice receded from the area. The highest evidence of submergence, at least in the southern part of Port au Port Bay and further south, is about $44 \mathrm{~m}$ above present sea level (Brookes et al., 1985; Grant, 1987). Radiocarbon ages determined on shells from marine sediments onshore range from 13.7 to $12.6 \mathrm{ka}$ (Table 1). A temporary break in the recession and local readvance produced icecontact deposits of the Robinsons Head Moraine. Estimates of the age of this event range from $12.6 \mathrm{ka}$ (Brookes, 1977b) to greater than $13.1 \mathrm{ka}$ (Grant, 1987). A thin veneer of early postglacial regressive marine deposits overlies the lower units in places around the margins of Port au Port and St. George's bays (Grant, 1991; Corney, 1992).

Marine geological surveys in St. George's Bay (Forbes and Shaw, 1989) have demonstrated that a major Late Wisconsinan ice margin extended across St. George's Bay to the Port au Port isthmus in the area of the present sill. Ice-contact deposits on the sill grade seaward into glacimarine facies, suggesting a grounded tide-water ice front (Shaw and Forbes, 1990b). Grant (1991) has suggested other moraines farther seaward, one south of the Port au Port Peninsula and another $40 \mathrm{~km}$ southwest of Robinsons Head (Fig. 1), where it may connect with the Late Wisconsinan limit onshore. These features, in present water depths of 50 to $135 \mathrm{~m}$, were interpreted from bathymetry and are unconfirmed. Figure 1 shows a conjectural ice limit after Grant (1987). Small areas of high ground on Table Mountain and the Lewis Hills apparently remained free of Late Wisconsinan ice (Grant, 1987, 1991).

\section{Relative sea-level changes}

The broad pattern of late- and postglacial sea-level changes in the Port au Port Bay area was established initially by Flint (1940), Shearer (1970), Brookes $(1969,1977 a)$, and Brookes et al. (1985), among others. These changes included rapid early emergence from a late-glacial maximum at least $44 \mathrm{~m}$ above present sea level at about $13.7 \mathrm{ka}$ [B.P.], sea level dropping below present prior to $9.5 \mathrm{ka}$ (Brookes et al., 1985), reaching a lowstand at least $11 \mathrm{~m}$ below present, and subsequently rising slowly over the past few thousand years. The age and depth of the Holocene lowstand were poorly constrained by a radiocarbon age of $5800 \pm 210$ years B.P. (GSC1203) on shell material from two cores collected in West Bay (Shearer in Lowdon et al., 1971; Table 1). On the basis of new radiocarbon dates from the Romaines River area, Grant (1987) proposed a revised sea-level history involving regression below present sea level before $12.7 \mathrm{ka}$ and a hypothetical minimum at $-20 \mathrm{~m}$ about 9 to $10 \mathrm{ka}$. New data presented in this paper demonstrate that relative sea level dropped to at least $25 \mathrm{~m}$ by about $9.5 \mathrm{ka}$ and had risen again to about $-10 \mathrm{~m}$ by 5.8 ka.

\section{Methods}

This paper is based primarily on data obtained during a four-day cruise in 1988. The work was carried out using a 20 $\mathrm{m}$ wooden-hulled research vessel (Navicula) based at the Bedford Institute of Oceanography, and consisted of day trips from the government wharf in Piccadilly Bay. This was one phase of a more extensive program including work in St. George's Bay (Shaw and Forbes, 1990b, 1992) and along the south coast of Newfoundland. Preliminary results and methods used for these surveys were summarized in the cruise report by Forbes and Shaw (1989). More detailed mapping in Port au Port Bay was undertaken as part of a contract study by Eddy (1989).

Survey line coverage in Port au Port Bay totalled $214 \mathrm{~km}$. The surveys were run at speeds of about 3 to 5 knots (1.5-2.6 $\mathrm{m} \mathrm{s}^{-1}$ ) and positioned by radar (estimated $\pm 25 \mathrm{~m}$ on fixes at ten-minute intervals) and Loran-C (estimated $\pm 50 \mathrm{~m}$ based on 


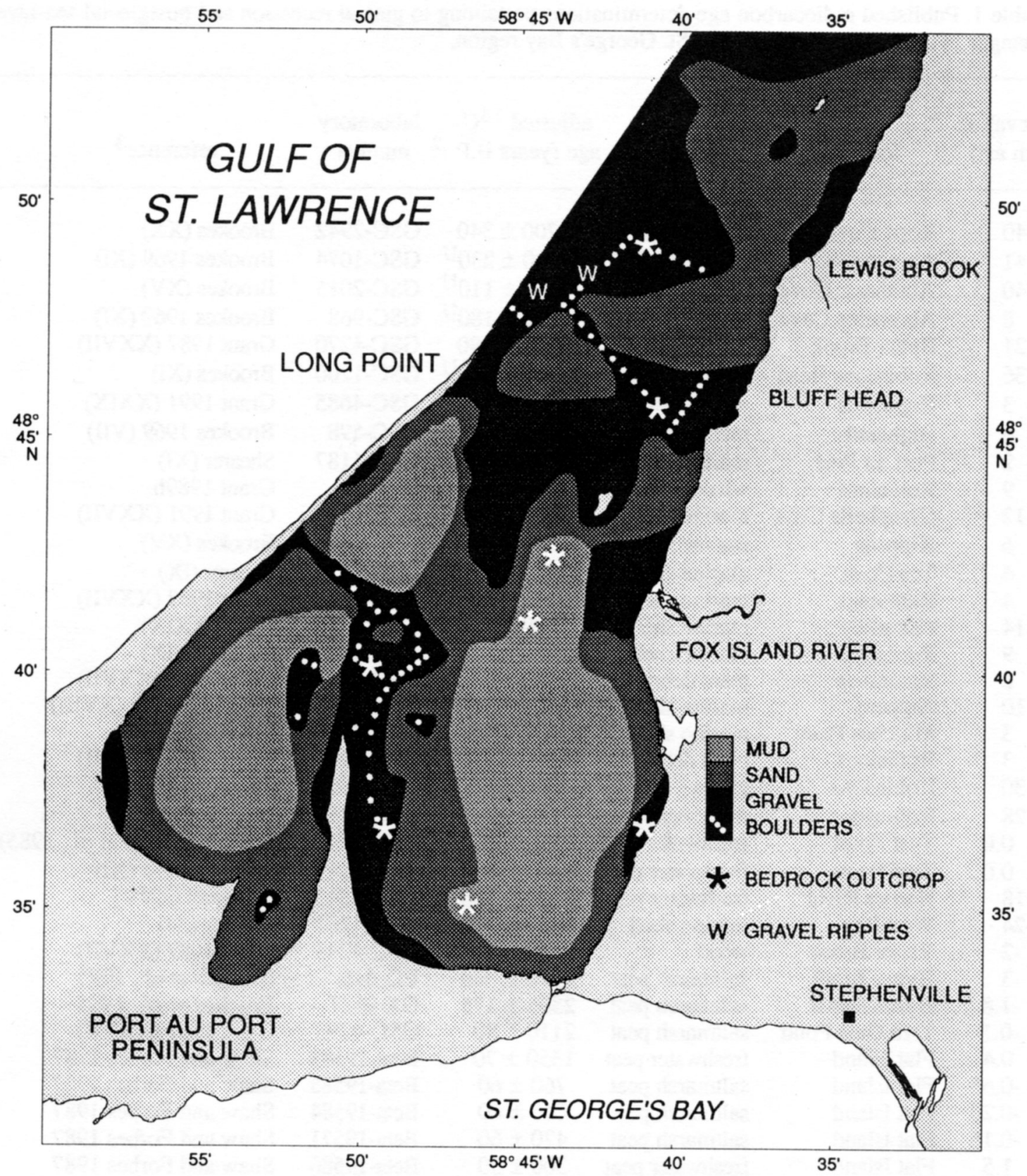

Fig. 4. Generalized distribution of surficial sediment types in Port au Port Bay, based on grab samples of Shearer (1970) and samples and sidescan sonar imagery collected for this study (Fig. 2). Also shown are locations of bedrock outcrop (*) and wave-formed ripples in gravel $(w)$.

raw time differences logged every minute). Some difficulties were encountered because of variable offsets in the Loran-C positions (related to the signal path over land) and the poor quality of the 1890s navigation charts for Port au Port Bay. The survey tracks and seabed sampling locations are shown in Figure 2.

Bathymetric data were obtained using a $30 \mathrm{kHz}$ Elac sounder and a hull-mounted transducer. Sidescan sonar imagery was collected with a dual-transponder $100 \mathrm{kHz}$ Klein towfish, displayed on wet paper on a Klein 421 recorder, and recorded on magnetic tape. The sidescan system was operated at a standard $100 \mathrm{~m}$ range (200 $\mathrm{m}$ swath) throughout the cruise. Shallow seismic data were obtained using three different systems: a Datasonics bubble pulser, a Huntec boomer (for a short time only), and a multitip sparker. The illustrations in this paper are taken exclusively from the sparker records. This system, which achieved a resolution of 2 to $8 \mathrm{~m}$ and penetration of more than $200 \mathrm{~m}$, utilized an ORE Geopulse 5210A receiver and NSRFC LT06 hydrophone streamer, with a $280 \mathrm{~J}, 20$-tip, surface-towed sparker as the sound source. The profiles were displayed on an EPC 4100 recorder, using a $250 \mathrm{~m}$ sweep, and recorded on magnetic tape. The bubble pulser used a $20 \mathrm{~J}$ coil mounted in a housing on the underside of a surfboard, which was towed just below the 
FORBES ET AL.

Table 1. Published radiocarbon age determinations pertaining to glacial recession and postglacial sea-level changes in the Port au Port Bay and St. George's Bay region.

\begin{tabular}{|c|c|c|c|c|c|}
\hline $\begin{array}{l}\text { elevation } \\
\text { ( } m \text { asl) }\end{array}$ & location 1 & material & $\begin{array}{l}\text { adjusted }{ }^{14} \mathrm{C} \\
\text { age (years B.P.) }\end{array}$ & $\begin{array}{l}\text { laboratory } \\
\text { number }\end{array}$ & reference $^{3}$ \\
\hline 40 & Rope Cove & marine shell & $13700 \pm 340$ & GSC-2942 & Brookes (XX) \\
\hline 41 & Abrahams Cove & marine shell & $13700 \pm 230^{U}$ & GSC-1074 & Brookes 1969 (XI) \\
\hline 40 & Abrahams Cove & marine shell & $13600 \pm 110^{\mathrm{U}}$ & GSC-2015 & Brookes (XV) \\
\hline 8 & Abrahams Cove & marine shell & $13600 \pm 180^{U}$ & GSC-968 & Brookes 1969 (XI) \\
\hline 21 & Butter Brook & marine shell & $13600 \pm 190$ & GSC -4270 & Grant 1987 (XXVII) \\
\hline 36 & Robinsons Head & marine shell & $13500 \pm 210^{\mathrm{U}}$ & GSC-1200 & Brookes (XI) \\
\hline 3 & Highlands & marine shell & $13500 \pm 120^{U}$ & GSC-4685 & Grant 1991 (XXIX) \\
\hline 6 & Highlands & marine shell & $13420 \pm 190^{\mathrm{U}}$ & GSC-598 & Brookes 1969 (VII) \\
\hline 2 & Port au Port & marine shell & $13400 \pm 290^{\mathrm{U}}$ & GSC- 1187 & Shearer (XI) \\
\hline 9 & Romaines & whale bone & $13345 \pm 230$ & S-3074 & Grant $1989 \mathrm{~b}$ \\
\hline 12 & Campbells Cove & marine shell & $13300 \pm 120$ & GSC -4346 & Grant 1991 (XXVII) \\
\hline 6 & Kippens & marine shell & $13300 \pm 810^{U}$ & GSC-2063 & Brookes (XV) \\
\hline 4 & Tea Cove & marine shell & $13200 \pm 220^{U}$ & GSC-937 & Shearer (IX) \\
\hline 4 & Romaines & marine shell & $13100 \pm 180$ & GSC-4095 & Grant 1987 (XXVII) \\
\hline 14 & Piccadilly & marine shell & $13000 \pm 110$ & GSC-4584 & Grant (XXIX) \\
\hline 9 & Romaines & marine shell & $12800 \pm 130$ & GSC-4858 & Grant (XXIX) \\
\hline 2 & Romaines & plant debris & $12700 \pm 110$ & GSC-4017 & Grant 1987 (XXVII) \\
\hline 10 & Kippens & marine shell & $12600 \pm 140$ & GSC-2295 & Brookes $1977 \mathrm{~b}$ (XVIII) \\
\hline 3 & Marches Point & marine shell & $12500 \pm 160$ & GSC-2496 & Brookes (XVIII) \\
\hline 3 & Romaines & plant debris & $11500 \pm 100$ & GSC -4291 & Grant 1987 (XXVII) \\
\hline 30 & Robinsons & gyttja & $11300 \pm 620$ & GX-9965 & Grant 1991 \\
\hline 28 & Robinsons & freshwater peat & $10600 \pm 150^{U}$ & GSC- 1350 & Brookes (XI) \\
\hline 0.0 & Turf Point & freshwater peat & $9350 \pm 120$ & WAT-883 & Davis (Brookes et al., 198 \\
\hline 0.0 & Turf Point & freshwater peat & $7340 \pm 200^{U}$ & GSC-1145 & Brookes 1974 (XI) \\
\hline 18 & Harry's River & freshwater peat & $6210 \pm 130$ & GSC -3342 & $\operatorname{Damman}(\mathrm{XXV})$ \\
\hline-24 & West Bay & marine shell & $5800 \pm 210$ & GSC-1203 & Shearer (XI) \\
\hline-2 & Victor Brook & wood & $2840 \pm 80$ & GSC-4243 & Grant 1987 (XXVII) \\
\hline-3 & Hynes Brook & saltmarsh peat & $2770 \pm 300$ & UQ-646 & Brookes et al., 1985 \\
\hline-1.8 & Hynes Brook & saltmarsh peat & $2365 \pm 175$ & GX-9527 & Brookes et al., 1985 \\
\hline-0.1 & Two Guts Pond & saltmarsh peat & $2110 \pm 80$ & GSC -4292 & Grant 1987 (XXVII) \\
\hline & Flat Island & freshwater peat & $1350 \pm 70$ & Beta-19583 & Shaw and Forbes 1987 \\
\hline-0.65 & Flat Island & saltmarsh peat & $760 \pm 60$ & Beta-19585 & Shaw and Forbes 1987 \\
\hline-0.20 & Flat Island & saltmarsh peat & $640 \pm 60$ & Beta-19584 & Shaw and Forbes 1987 \\
\hline-0.15 & Flat Island & saltmarsh peat & $470 \pm 60$ & Beta-19571 & Shaw and Forbes 1987 \\
\hline 1.5 & Flat Island & freshwater peat & $300 \pm 50$ & Beta-19586 & Shaw and Forbes 1987 \\
\hline
\end{tabular}

$\begin{aligned} &{ }^{1} \text { Locations of most dates are shown on Grant's (199 } \\ &{ }^{2} \text { GSC determinations on marine shells are adjusted } \\ &{ }^{3} \text { Roman numerals in parentheses refer to GSC date } \\ & \text { VII } \quad \text { Lowdon and Blake (1968) } \\ & \text { IX } \quad \text { Lowdon and Blake (1970) } \\ & \text { XI } \text { Lowdon et al. (1971) } \\ & \text { XV } \text { Lowdon and Blake (1975) } \\ & \text { XVIII } \text { Lowdon and Blake (1978) } \\ & \text { XX } \text { Lowdon and Blake (1980) } \\ & \text { XXV } \text { Blake (1986) } \\ & \text { XXVII } \text { Blake (1988) } \\ & \text { XXIX } \text { McNeely and McCuaig (1991) }\end{aligned}$

water surface. The records were displayed on an EPC 1600s thermal recorder with a $190 \mathrm{~m}$ sweep. Despite its low power, this system produced excellent records down to bedrock in most places, but the wide bubble pulse limited the resolution to $10 \mathrm{~m}$ at best. All sidescan sonar and shallow seismic records were marked with day+time at two-minute intervals using a TSS 312B record annotator.

Interpretation of the shallow seismic records was hin- 
dered by the strong bubble pulse, which obscured nearbottom structures on both the bubble-pulser and the sparker profiles. Strong surface multiples and extensive gas masking posed additional problems. Estimates of sediment thickness in this paper are based on an assumed sound velocity of 1500 $\mathrm{m} \mathrm{s}^{-1}$ (e.g., a two-way travel time of $100 \mathrm{~m}$ is equivalent to 75 $\mathrm{m})$. In reality, acoustic velocities in these sediments may range from $1600 \mathrm{~m} \mathrm{~s}^{-1}$ or less in mud to $3000 \mathrm{~m} \mathrm{~s}^{-1}$ or more in compact material such as glacial diamict. Therefore, the true thicknesses of some sections, particularly in unit 1 , may be up to two times the values quoted.

A total of 23 van Veen grab samples and 4 short cores (maximum length $1.8 \mathrm{~m}$ ) were recovered in Port au Port Bay during the Navicula program. The core lengths were limited by the size and handling capability of the vessel, which restricted us to use of a $3 \mathrm{~m}$ Alpine gravity corer.

Radiocarbon age determinations were obtained on five samples of marine molluscs from two of the cores and on three peat samples from a coastal exposure. Together with 35 published ${ }^{14} \mathrm{C}$ ages from late- and postglacial deposits in the region, these have been used to constrain the range and timing of changes in relative sea level during the past $14 \mathrm{ka}$ (Tables 1,2). Careful attention has been paid to the stratigra- phic context of each sample and to the methods employed by the various radiocarbon laboratories. In cases where ${ }^{14} \mathrm{C}$ age determinations are adjusted to $\delta^{13} \mathrm{C}=-25 \%$, an assumed marine reservoir age of about 400 years (cf. Mangerud and Gulliksen, 1975; Bard, 1988) has been subtracted from the $\delta^{13} \mathrm{C}$-adjusted age. In other cases, notably marine shell ages from the Geological Survey of Canada (GSC) laboratory, where the policy has been to adjust results to $\delta^{13} \mathrm{C}=0 \%$, the $\sim 400$ year reservoir is already incorporated in the published age (Lowdon, 1985). A number of early ${ }^{14} \mathrm{C}$ results from the GSC laboratory were done before the determination of $\delta^{13} \mathrm{C}$ became routine; the reported ages for these samples are unadjusted (Table 1). Calibration of the ${ }^{14} \mathrm{C}$ time scale against tree-ring calendars, varved sequences, or other isotopic methods such as ${ }^{234} \mathrm{U}-{ }^{230} \mathrm{Th}$ dating indicates both non-linear errors and a significant negative bias (underestimation of true age) for ${ }^{14} \mathrm{C}$ estimates, amounting to as much as 1000 years at 8500 radiocarbon years B.P. (e.g., Becker et al., 1991) and more for ages greater than $10 \mathrm{ka}$ (e.g., Bard et al., 1990). The use, by international convention, of an assumed ${ }^{14} \mathrm{C}$ half-life of 5568 years rather than the correct value of 5730 years exacerbates this bias. However, because of uncertainty about the geographic and temporal range of oceanic reservoir ages

Table 2. Radiocarbon age determinations on samples from Port au Port Bay.

\begin{tabular}{|c|c|c|c|c|}
\hline no. 1 & $\begin{array}{l}\text { depth in } \\
\text { core }(m)\end{array}$ & material & $\begin{array}{c}\text { adjusted }{ }^{14} \mathrm{C} \text { age }^{2} \\
\text { (years B.P.) }\end{array}$ & $\begin{array}{l}\text { laboratory } \\
\text { number }\end{array}$ \\
\hline $\begin{array}{l}1 \\
2\end{array}$ & $\begin{array}{l}0.32 \\
1.35\end{array}$ & $\begin{array}{l}\text { Astarte undata pv } \\
\text { Portlandia arctica pv }\end{array}$ & $\begin{array}{l}11340 \pm 200 \\
13310 \pm 230\end{array}$ & $\begin{array}{l}\text { Beta-88063/ ETH-50423 } \\
\text { Beta-88061/ ETH-5040 }\end{array}$ \\
\hline core 8 & $\begin{array}{l}3-20 \text { (water } \\
\text { depth in } \\
\text { core }(m)\end{array}$ & material & $\begin{array}{c}\text { adjusted }{ }^{14} \mathrm{C} \text { age } \\
\text { (years B.P.) }\end{array}$ & $\begin{array}{l}\text { laboratory } \\
\text { number }\end{array}$ \\
\hline $\begin{array}{l}3 \\
4 \\
5\end{array}$ & $\begin{array}{l}0.55 \\
1.02 \\
1.08\end{array}$ & $\begin{array}{l}\text { Spisula polynyma pv }\left(\delta^{13} \mathrm{C}=2.6 \%\right) \\
\text { Astarte undata pv } \\
\text { A. undata, Nuculana pernula } 2 \mathrm{pv}\end{array}$ & $\begin{array}{r}9570 \pm 150 \\
10930 \pm 200 \\
10765 \pm 190\end{array}$ & $\begin{array}{l}\text { GSC-4724 } \\
\text { Beta-88064/ ETH-50433 } \\
\text { Beta-88062/ ETH-5041 }\end{array}$ \\
\hline
\end{tabular}

section 16 (base of peat $0.1 \mathrm{~m}$ above MWL)

\begin{tabular}{ccccc}
\multicolumn{2}{c}{$\begin{array}{c}\text { elev. above } \\
\text { no. }\end{array}$} & material & $\begin{array}{c}\text { adjusted }{ }^{14} \mathrm{C} \text { age } \\
\text { (years B.P.) }\end{array}$ & $\begin{array}{c}\text { laboratory } \\
\text { number }\end{array}$ \\
\hline 6 & 1.00 & Sphagnum peat $\left(\delta^{13} \mathrm{C}=-26.0 \%\right)$ & $2890 \pm 140$ & Beta-36167 \\
7 & 0.40 & Ericaceous peat $\left(\delta^{13} \mathrm{C}=-27.4 \%\right)$ & $4590 \pm 180$ & Beta-36168 \\
8 & 0.00 & monocot. peat $\left(\delta^{13} \mathrm{C}=-29.1 \%\right)$ & $9020 \pm 100$ & GSC-4733 \\
\hline
\end{tabular}

${ }^{1}$ See Figure 15.

${ }^{2}$ All Beta/ETH ages have been normalized to $\delta^{13} \mathrm{C}=-25.0 \%$. Ages of marine shells have been further adjusted for the approximate oceanic reservoir effect by subtracting 400 years from the $\delta^{13} \mathrm{C}$-adjusted age. GSC-4724 was normalized to $\delta^{13} \mathrm{C}=0 \%$, following standard procedure in the GSC laboratory. No reservoir adjustment has been made in this case. pv denotes paired valves, $2 \mathrm{pv}$ denotes two pairs. Note: analytical uncertainty is shown as $\pm 2 \sigma$ for all ages (most labs except the GSC quote $\pm 1 \sigma$ ).

${ }^{3}$ Samples with ETH numbers are AMS. 
(Bard, 1988) and a variety of other potential errors (Lowdon, 1985), we have opted to make no further adjustments at this time.

\section{Quaternary Deposits in Port Au Port Bay}

\section{Surficial sediments and bathymetry}

\section{Seabed sediments and bedrock}

The distribution of seabed sediments in Port au Port Bay was mapped by Shearer (1970) on the basis of 130 grab samples for which he completed detailed textural analyses. Shearer distinguished three sediment types: bimodal silts and clays, unimodal sands, and bimodal gravels. He showed that the finer sediments are confined to low-energy basin settings, while the sands and gravels occur in shallower areas subjected to higher wave and tidal current energy. With additional sample and sidescan sonar data from the present study, our understanding of surficial deposits in the bay is altered only in detail.

As in St. George's Bay to the south (Shaw and Forbes, 1990b), we have defined three generalized seabed sediment types on the basis of modal grain size. These are (i) mud and sandy mud; (ii) sand, muddy sand, and gravelly sand; and (iii) gravel and sandy gravel. The distribution of these sediment types has been mapped primarily from grab sample data (Shearer, 1970; Forbes and Shaw, 1989; Fig. 4). Two additional bottom types--(iv) coarse gravel with boulders and (v) bedrock outcrop--have been mapped from sidescan sonar imagery where available (Figs. 2, 4).

Muds and sandy muds form the sea floor in the deep central basin of East Bay, typically in water depths greater than 20 to $30 \mathrm{~m}$. They also cover two broad areas along the central axis of West Bay, primarily in water depths greater than $15 \mathrm{~m}$, but with less obvious bathymetric control than in East Bay.

Sands predominate in intermediate depths and extend onshore in some areas, particularly in southern West Bay, along the east side of the Long Point peninsula, at the south end of East Bay near Port au Port, in the vicinity of the beach south of Fox Island River to Two Guts Pond, and along the coast on the northeast side of "Fox Basin" opposite Shag Island.

Gravels are found close to shore along the west side of West Bay, over a broad area in the vicinity of Shoal Point and south along the east side of the point to the south end of East Bay. They also occur along the eastern shore near Black Point. Gravel covers the submerged delta terrace off Fox Island River, extends over a large area of the central bay from south of Bluff Head to Long Point including the wide shoal west of Fox Island, and occupies a large triangular area between Long Point, Long Ledge, and "Fox Basin" (opposite Bluff Head). Although our 1988 surveys did not extend into "Serpentine Basin", samples recovered by Shearer (1970) from north of Shag Island indicate a gravel-dominated seafloor throughout that area. Wave-formed gravel ripples occur east of Long Point, in an area directly exposed to waves from the open gulf (Fig. 4).

Relatively immobile (probably lag) accumulations of coarse gravel and boulders are recognized on the sidescan sonar imagery in several parts of the bay, generally in water depths less than $15 \mathrm{~m}$. These include the area north and east of Shoal Point, at the south end of the shoal west of Fox Island, near Black Point, and at many locations from Long Point to the northeast and across the bay to the east coast south of Bluff Head.

Bedrock can be seen on the sidescan sonar records at a number of locations in Port au Port Bay (Fig. 4). The sediment cover on the ridges between basins is typically thin and locally absent, revealing exposures of bedrock (e.g., north of Shoal Point). We have also observed bedrock outcrop locally on the flanks of Shoal Point in both West and East bays, near Black Point and north of Fox Island, and in deeper water (25$30 \mathrm{~m}$ ) in southem East Bay. Shearer (1970) undertook SCUBA dives on a number of outcrop targets in the bay and identified Humber Arm volcanics and St. George Group silty limestone along the ridge between Fox Island and Shoal Point; sandstone of the Humber Arm Group west of Fox Island, southeast of Shoal Point, and southwest of Shag Island; silty limestone west of Shoal Point; and siltstone and shale in shallow water along the west and southwest sides of "Fox Basin". The presence of bedrock at or close to the seabed on inter-basin shoals suggests that the basins are excavated in rock and are therefore of glacial origin.

\section{Bathymetry}

Detailed bathymetric surveys, particularly in the northem part of East Bay between Black Point and Fox Island (Fig. 3 ), have revealed a complex set of submerged deltaic terraces seaward of Fox Island River. These are marked by abrupt breaks in slope at various depths between 12 and $26 \mathrm{~m}$, frequently associated with textural changes from coarser sediment on the terrace to finer sediment at the base of the slope. These features are interpreted to represent deltaic sedimentation at falling, stationary, and rising water levels between present sea level and the East Bay sill depth at about $26 \mathrm{~m}$. Also noteworthy is the depression more than $60 \mathrm{~m}$ deep immediately in front of the outermost and deepest delta terrace off Fox Island River (Fig. 3). This is the deepest point in East Bay and is interpreted as an area of non-deposition or scour associated with tidal currents in what would have been a progressively constricted passage between the submerged delta and the Fox Island shoreline (less than $1 \mathrm{~km}$ wide at -25 $\mathrm{m})$. Erosional terraces at or below $25 \mathrm{~m}$ present water depth are found in other parts of the bay, particularly in areas where the limited wave energy at lower water levels would be greatest (Fig. 3). In some places these are seen to truncate pre- or early-Holocene marine deposits (Fig. 5). We interpret these features as shoreface erosional terraces associated with a lowstand water level at about $-25 \mathrm{~m}$. 


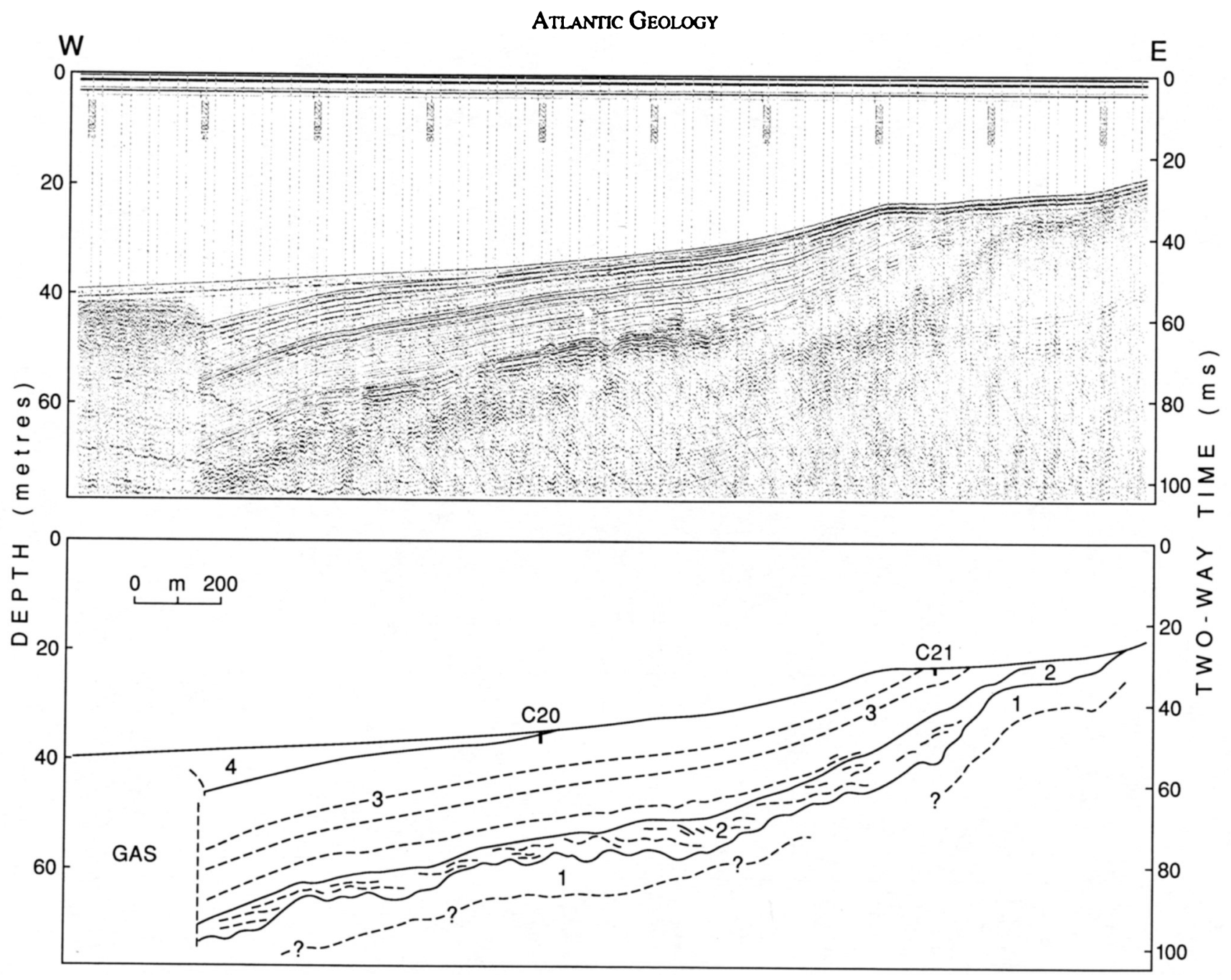

Fig. 5. Surface-tow sparker profile across lowstand shoreline on east side of East Bay, southwest of Two Guts Pond (see Fig. 2 for location). Approximate positions of cores 8-20 and 8-21 are also shown. Erosional bench at about $25 \mathrm{~m}$ present water depth truncates draped deposits of unit 3 . Gas is present in basin-thickening wedge of unit 4 mud at left.

\section{Acoustic stratigraphy}

The total thickness of Late Quaternary sediments in Port au Port Bay varies greatly between basins and from basins to shoals. The maximum thickness ( $>50 \mathrm{~m}$ ) occurs in East Bay, where the base of the Late Quaternary section in the deepest part of the basin is obscured by gas (Fig. 5). Thicknesses in excess of $25 \mathrm{~m}$ are found in "Fox Basin". Our surveys did not extend into "Serpentine Basin" and the thickness of Quaternary sediments there is unknown at present. Among the basins for which data are available, West Bay contains the least sediment, although the thickness of Late Quaternary deposits may increase westward beyond the range of our survey coverage.

On the basis of acoustic signature and geometry, we identify six major acoustic units overlying bedrock in Port au Port Bay. These are as follows:

(1) an acoustically unstratified unit, including till and other ice contact deposits, representing the products of deposition or loading by grounded glacial ice or of other ice-contact processes;

(2) a crudely stratified unit, believed to be mainly ice-contact or ice-proximal sand and gravel;
(3) a conformably stratified unit, interpreted as glacimarine and early paraglacial sandy silt and clay;

(4) a weakly-stratified to acoustically transparent unit consisting of postglacial mud;

(5) a wedge-shaped unit dominated by clinoform reflections, representing postglacial deltaic sand and gravel in submerged terraces off Fox Island River; and

(6) thin wedges of acoustically stratified deposits, considered to represent transgressive shoreface, late-delta, and tidal units of sand and gravel.

Some units are absent from the section in many parts of the bay. Acoustic units 1 to 6 are equivalent to units $A$ to $F$ of Eddy (1989). Although differing in many details, broadly similar sequences of seismostratigraphic units have been described from elsewhere around the coast of Newfoundland (e.g., Dale and Haworth, 1979; Fader et al., 1982; Shaw and Forbes, 1990b; Josenhans et al., 1990; Jenner and Shaw, 1992), from the St. Lawrence Estuary (Syvitski and Praeg, 1989), and from other marine areas in southeastern Canada (e.g., Piper et al., 1983; King and Fader, 1986; Forbes et al., 1991; Syvitski, 1992).

Unit 1. This unit (Figs. 5,6) is characterized on sparker profiles by a dark acoustic tone, high-amplitude incoherent 


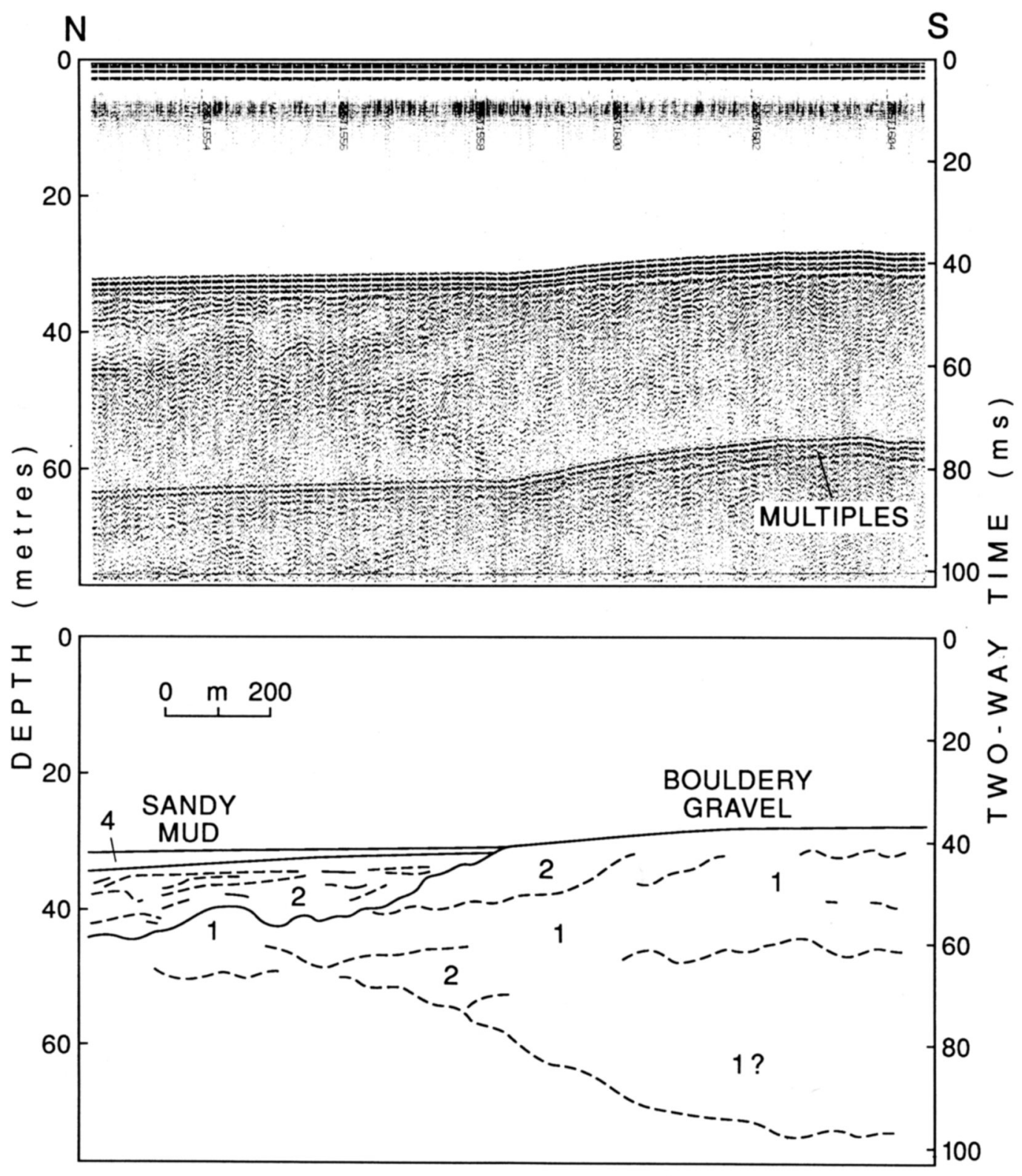

Fig. 6. Surface-tow sparker profile from "Fox Basin" in Port au Port Bay, showing units 1 and 2 (see Fig. 2 for location). Thin overlying wedge of unit 4 is relatively sandy at this location. This area of deeper water off Bluff Head is the only part of Port au Port Bay surveyed where unit 1 attains a thickness greater than $25 \mathrm{~m}$ (Fig. 7).

reflections, and a hummocky upper surface, except where eroded. Where unit 1 is exposed at the sea bed, the sidescan records typically display a dark and irregular tone with numerous point reflections from boulders. Unit 1 is observed almost ubiquitously as the lowermost unit of the Late Quaternary section in the study area. Its base is rarely discernible on our seismic records. The thickness (where seen) is generally less than $25 \mathrm{~m}$, except in a band approximately $2 \mathrm{~km}$ wide parallel to the present coast off Bluff Head (Fig. 7). Unit 1 is interpreted as an unstratified ice-contact deposit, much of which may be glacial till of Late Wisconsinan age. Coherent internal reflections within unit 1 near Bluff Head (Fig. 6) suggest multiple phases of ice-contact deposition including crudely stratified subglacial or ice-front deposits that grade irregularly into overlying and adjacent deposits of unit 2.

Unit 2 . This unit occurs in geometrically irregular bodies overlying and interbedded with unit 1 (Fig. 6). It is characterized by high-amplitude, weakly-coherent, sub-horizontal reflections in pockets up to $8 \mathrm{~m}$ or more in thickness (Figs. 6, 8 ). In the area south of Bluff Head, these deposits show evidence of northward progradation (Fig. 6). Unit 2 is interpreted on the basis of stratigraphic position and similarity to equivalent units in other areas (e.g., Syvitski and Praeg, 1989) to represent stratified ice-contact or proximal meltwater deposits of sand and gravel. Although we cannot resolve diagnostic structures in the seismic profiles, we suspect that part of unit 2 was deposited subglacially, but that much of it was delivered to subaqueous ice-front fans (cf. Rust, 1977; 


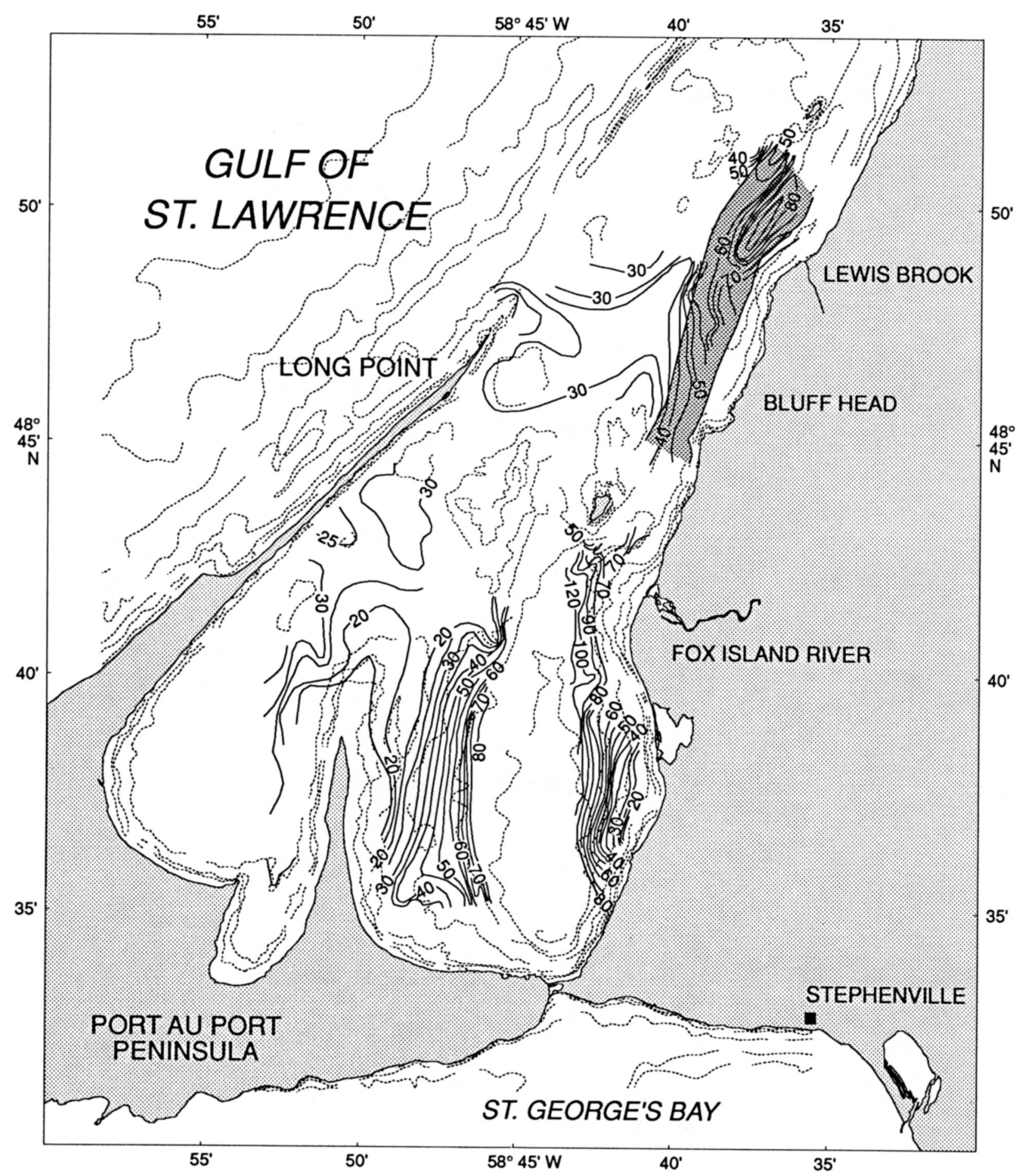

Fig. 7. Topography on upper surface of units 1 and 2 or bedrock where these are absent (after Eddy, 1989). Depths in milliseconds (twoway travel time) below present mean sea level. Note shallow basin in West Bay and contrasting line of deep basins parallel to coast from East Bay north to "Fox Basin" (Fig. 2). Maximum depth to unit 1 in East Bay is obscured by shallow gas (see Fig. 10). Stipple indicates area where the thickness of unit 1 exceeds $25 \mathrm{~m}$. Broken lines show general bathymetric form (see Fig. 2).

Shaw, 1985; Sharpe, 1988). Unit 2 represents a small proportion of the total sediment fill in Port au Port Bay.

Unit 3. This unit consists of moderate- to high-amplitude, closely-spaced, coherent, parallel reflections draped conformably over underlying deposits of units 1 or 2 (Figs. 5 , 8). Reflections can be traced laterally for distances of 2 to 3 $\mathrm{km}$ or more within individual basins. Unit 3 ranges in thickness up to $45 \mathrm{~m}$ or more in East Bay (Fig. 9). The greatest thickness is believed to occur in the deepest part of this basin where the section is obscured by shallow gas (Fig. 5). Unit 3 exceeds $22 \mathrm{~m}$ in thickness off Lewis Brook in "Fox Basin", but is essentially absent in West Bay. In places, unit 3 


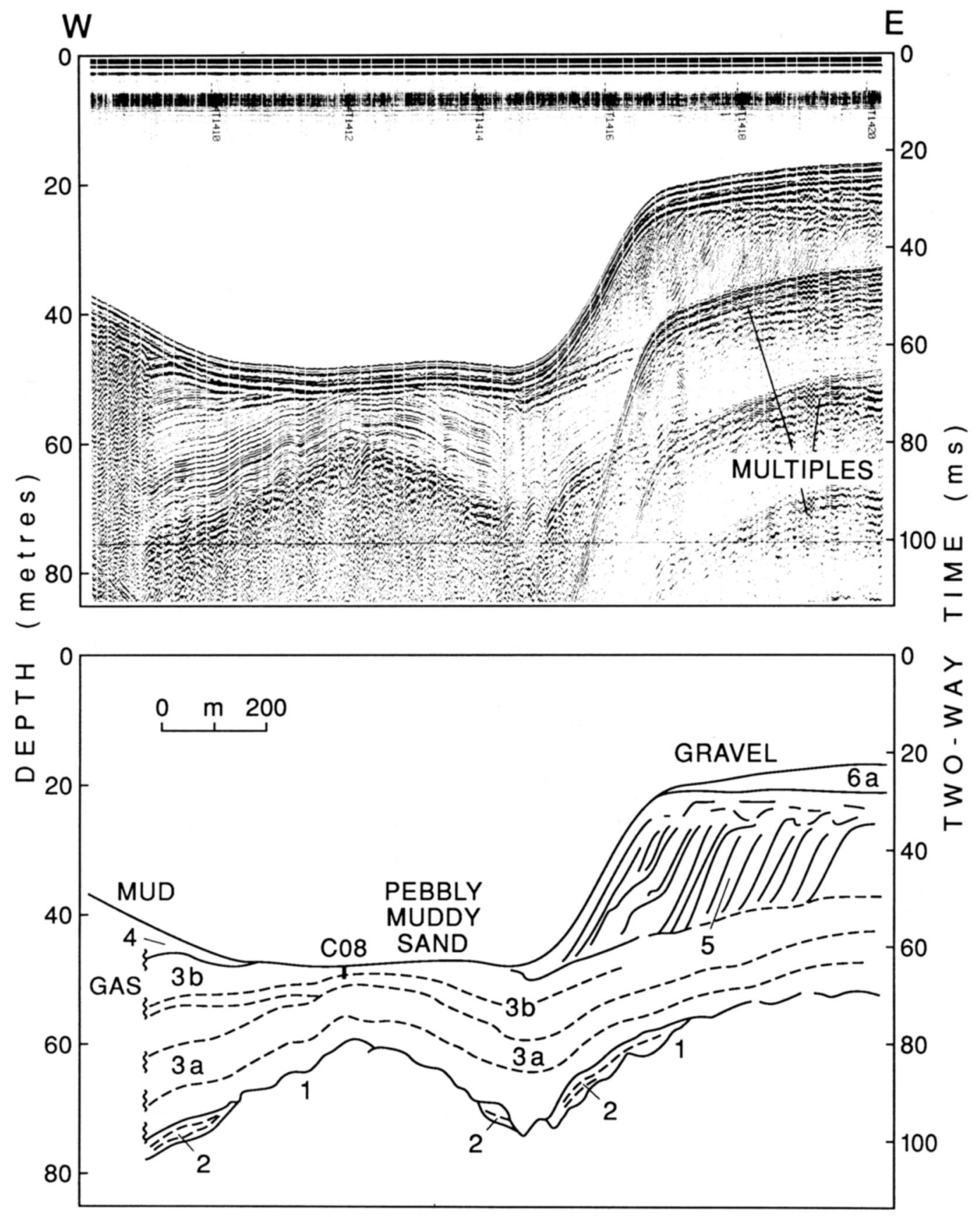

Fig. 8. Surface-tow sparker profile across submerged lowstand delta terrace of Fox Island River (see Fig. 2 for location), showing topset/ foreset contact at approximately $27 \mathrm{~m}$ below present mean water level. Delta foresets prograded basinward over draped glacimarine and early paraglacial deposits of unit 3. Projected position of core 8 ("C 08 ") is also shown.

displays an upward decrease in reflectivity, possibly implying a reduction in the proportion of the coarse fraction (sand and gravel). In a few places (e.g., Fig. 8), as also in nearby St. George's Bay (Shaw and Forbes, 1990b), this unit can be subdivided into a lower draped unit (3a) and an upper partially ponded unit (3b). Unit 3 is interpreted as a glacimarine mud with a high proportion of silt, containing ice-rafted sand and dropstones. We suspect that this unit was deposited in large part by suspension fallout in a marine proglacial or early paraglacial setting (see Syvitski, 1989).

Unit 4 . This unit (Figs. 5,8 ) is characterized by very faint acoustic stratification and is almost acoustically transparent in many places. It is present as a ponded unit at least $3 \mathrm{~m}$ thick in West Bay (up to $8 \mathrm{~m}$ or more to the north inside Long Point). In East Bay, the thickness of ponded unit 4 deposits increases with depth to approximately $8 \mathrm{~m}$, beyond which gas obscures the stratigraphy over much of the deepest part of the bay (Fig. 10). A distinctive occurrence of unit 4, recognized by Eddy (1989) as a sub-unit (his unit Db), occurs with positive relief in northern West Bay south of Fox Island. Here too the unit contains gas and therefore the thickness and underlying stratigraphy are obscured. Ponded deposits of 


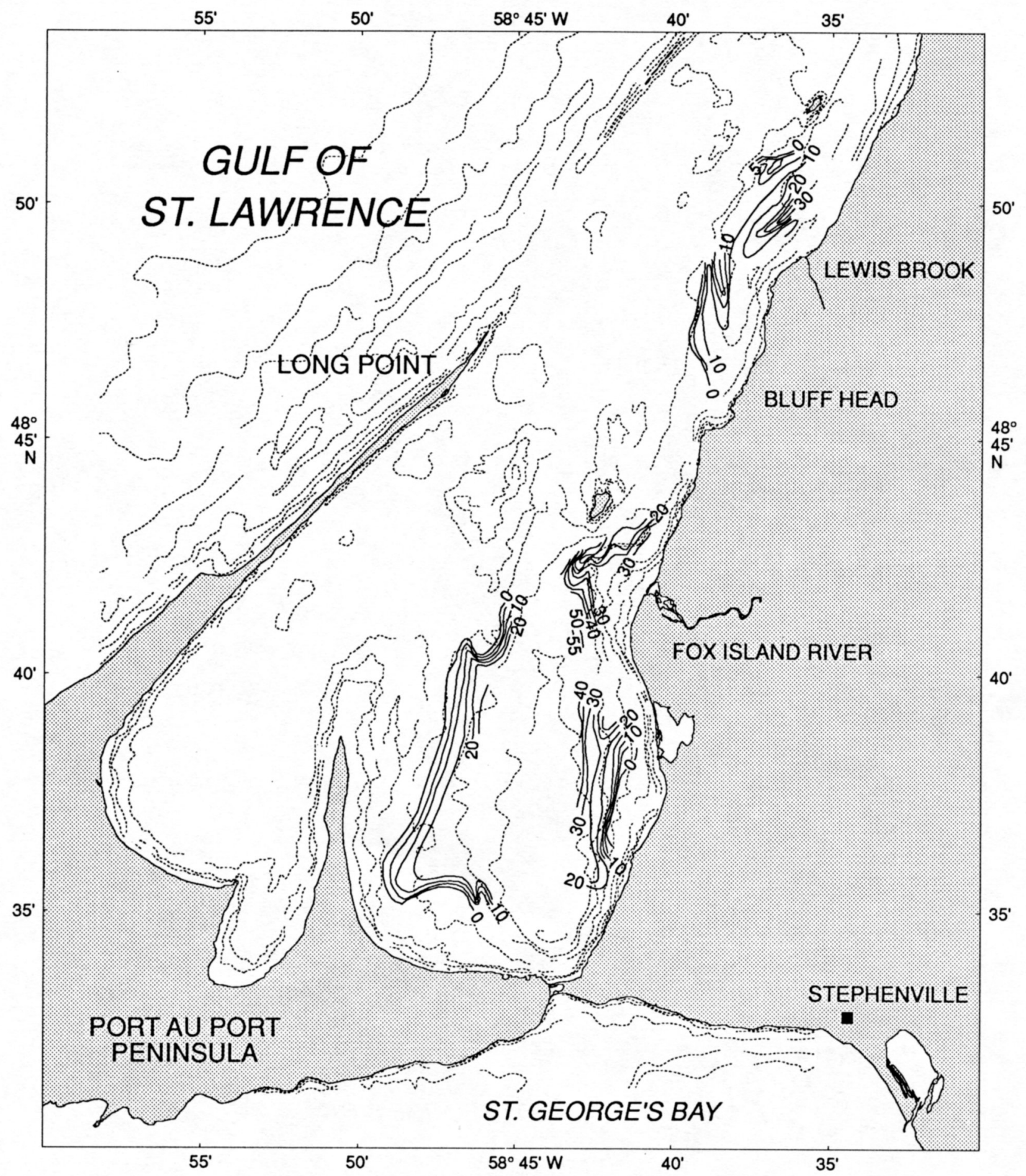

Fig. 9. Isopachs of unit 3 in Port au Port Bay (after Eddy, 1989). Units are milliseconds two-way travel time. Broken lines show general bathymetric form (see Fig. 2).

unit 4 are thin or absent in "Fox Basin" and may also be missing from "Serpentine Basin" where the seabed sediments sampled by Shearer (1970) were all gravel. Unit 4 is interpreted as postglacial mud deposited under a wide range of depth, energy, and salinity conditions (see below).

Unit 5. This unit is characterized by a wedge-shaped geometry, terraced in places, with clinoform reflections of moderate amplitude dipping basinward at angles up to $12^{\circ}$ or more (Fig. 8). The clinoform wedges of unit 5 are bounded at top and bottom by sub-horizontal reflections of varying character, particularly in the upper bounding units, which are locally channelled. Unit 5 is interpreted to represent sands and gravels of steep-fronted, foreset-dominated, coarsegrained "Gilbert" deltas (Gilbert, 1885, 1890; Postma, 1990), deposited at lower relative sea levels off Fox Island River and Lewis Brook. 


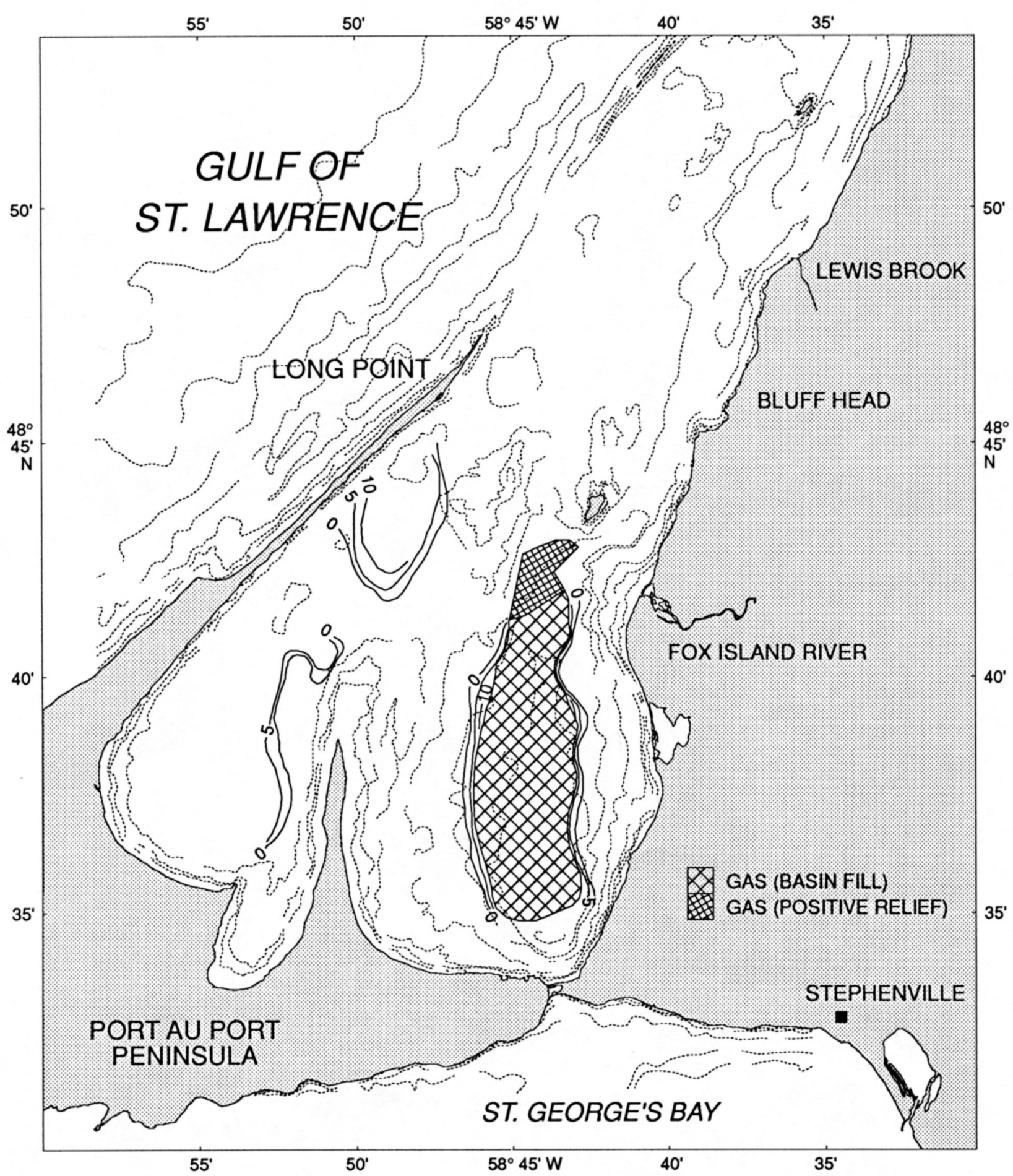

Fig. 10. Isopachs of unit 4 in Port au Port Bay (after Eddy, 1989). Units are milliseconds two-way travel time. Broken lines show general bathymetric form (see Fig. 2).

Unit 6. Two sub-units are recognized within unit 6 . The first, unit $6 \mathrm{a}$, is typically less than $8 \mathrm{~m}$ thick and is characterized by moderate- to high-amplitude reflections, either horizontal or dipping gently basinward, lying unconformably over deposits of unit 5 in the vicinity of Fox Island River (Fig. 8). Unit 6a is interpreted as a shoreface wedge of sand and gravel, representing transgressive marine reworking of deltaic deposits off Fox Island River. It may also include bot- tomset units of later delta bodies deposited under rising relative sea levels on top of the lowstand deltas of unit 5 , similar to the stacked deltas described by Thors and Boulton (1991).

The second subdivision, unit $6 \mathrm{~b}$, takes the form of moderate-amplitude low-angle reflections forming thin progradational packages with positive relief up to about 7 or $8 \mathrm{~m}$ (Fig. 11). These rest unconformably over deposits of unit 1 or 


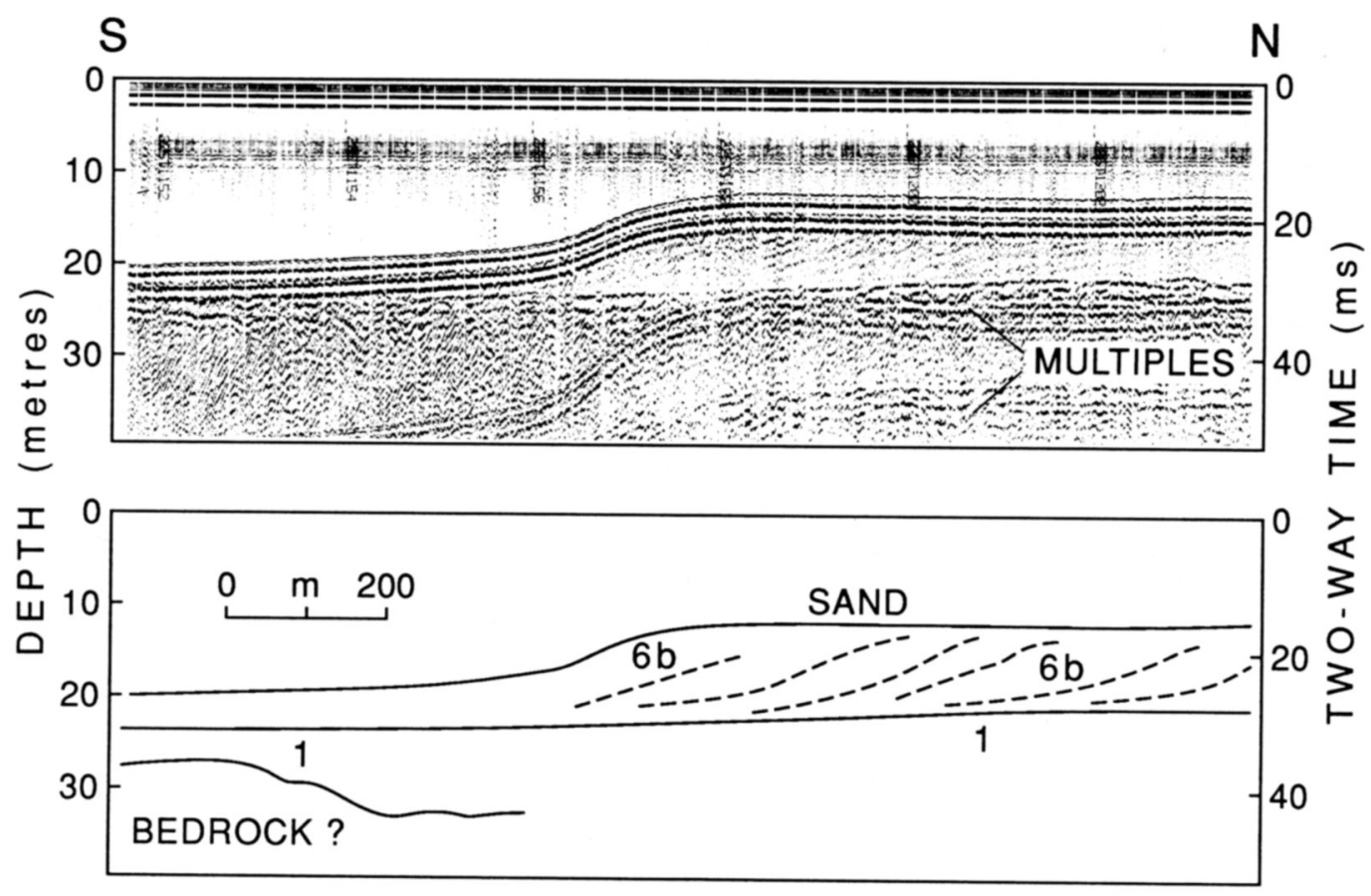

Fig. 11. Surface-tow sparker profile across wedge of unit $6 \mathrm{~b}$ sand prograding southward over truncated deposits of unit 1 between Fox Island and Long Point (see Fig. 2 for location).

2 (locally 3) inside the northern tip of Long Point and along the western margin of "Fox Basin" south of Shag Island. The direction of progradation is approximately toward the south between Long Point and Fox Island, but roughly eastward in the area between Fox and Shag islands. Unit $6 \mathrm{~b}$ appears to represent flood-tidal reworking of sand associated with currents entering the bay between Long Point and Long Ledge, spreading southward into West Bay and eastward into deeper water south of Shag Island. Wave motions may also play a part, as suggested by the occurrence of gravel ripples on top of unit $6 \mathrm{~b}$ sediments east of Long Point (Fig. 4).

\section{Core stratigraphy}

Sampling operations in Port au Port Bay during 1988 yielded four short gravity cores, ranging in length from 0.86 to $1.80 \mathrm{~m}$ (Fig. 12). Despite their short length, three of these cores (8-08, 8-20, and 8-21) penetrated glacimarine deposits of unit 3. Radiocarbon determinations on marine bivalves in two of the cores (Table 2) have provided new data on the chronology of sedimentation and relative sea-level fluctuations in the bay.

\section{Core 8-08}

This core was obtained in $43 \mathrm{~m}$ water depth seaward of the present mouth of Fox Island River, at the north end of a deep basin adjacent to the relict delta front (Fig. 3). The core is $1.46 \mathrm{~m}$ long (Fig. 12), consisting of about $0.12 \mathrm{~m}$ of greybrown pebbly coarse sand with an erosional base, overlying about $0.12 \mathrm{~m}$ of grey-brown pebbly silt. This is underlain by at least $1.23 \mathrm{~m}$ of dark grey clay containing sand lenses and pebbles in the uppermost part.

Shell fragments and a complete gastropod shell were present in the upper sand unit and more shell fragments were found in the silt and the upper part of the mud. A complete specimen (valves in apparent growth position) of Astarte undata Gould, collected from the upper part of the grey mud, $0.32 \mathrm{~m}$ down-core, gave an adjusted AMS age of 11,340 \pm 200 radiocarbon years B.P. (Beta-88063/ETH-5042; Table 2; Fig. 12). Paired valves of Portlandia arctica (Gray) from $1.35 \mathrm{~m}$ below sea bed, near the base of the core, produced an adjusted AMS age of 13,310 \pm 230 years B.P. (Beta-88061/ ETH-5040; Table 2).

The lower mud in core 8-08 is interpreted to represent an early paraglacial draped marine deposit of acoustic unit 3 , possibly proglacial at the base. At the core site, the top of this unit has apparently been removed by erosion (Fig. 8). The overlying grey-brown silt may be part of the same unit or it may be associated with surface winnowing. The upper veneer of sand may be a lag deposit resulting from erosion of the underlying sediments or it may be the thin edge of an extensive sand sheet occurring north of the sampling site in the passage between Fox Island and the mainland (Fig. 3).

\section{Core 8-20}

This core was obtained in $36 \mathrm{~m}$ water depth on the eastern margin of East Bay just south of Two Guts Pond (Figs. 3, 5). The core is $1.80 \mathrm{~m}$ long (Fig. 12). It consists of $0.37 \mathrm{~m}$ of black to olive-grey silty clay, soft, mottled, faintly laminated in the upper $0.17 \mathrm{~m}$. This mud grades into an underlying coarse unit, $0.25 \mathrm{~m}$ thick, consisting of interbedded muddy fine sand with pebbles and coarse sand. Underlying the 


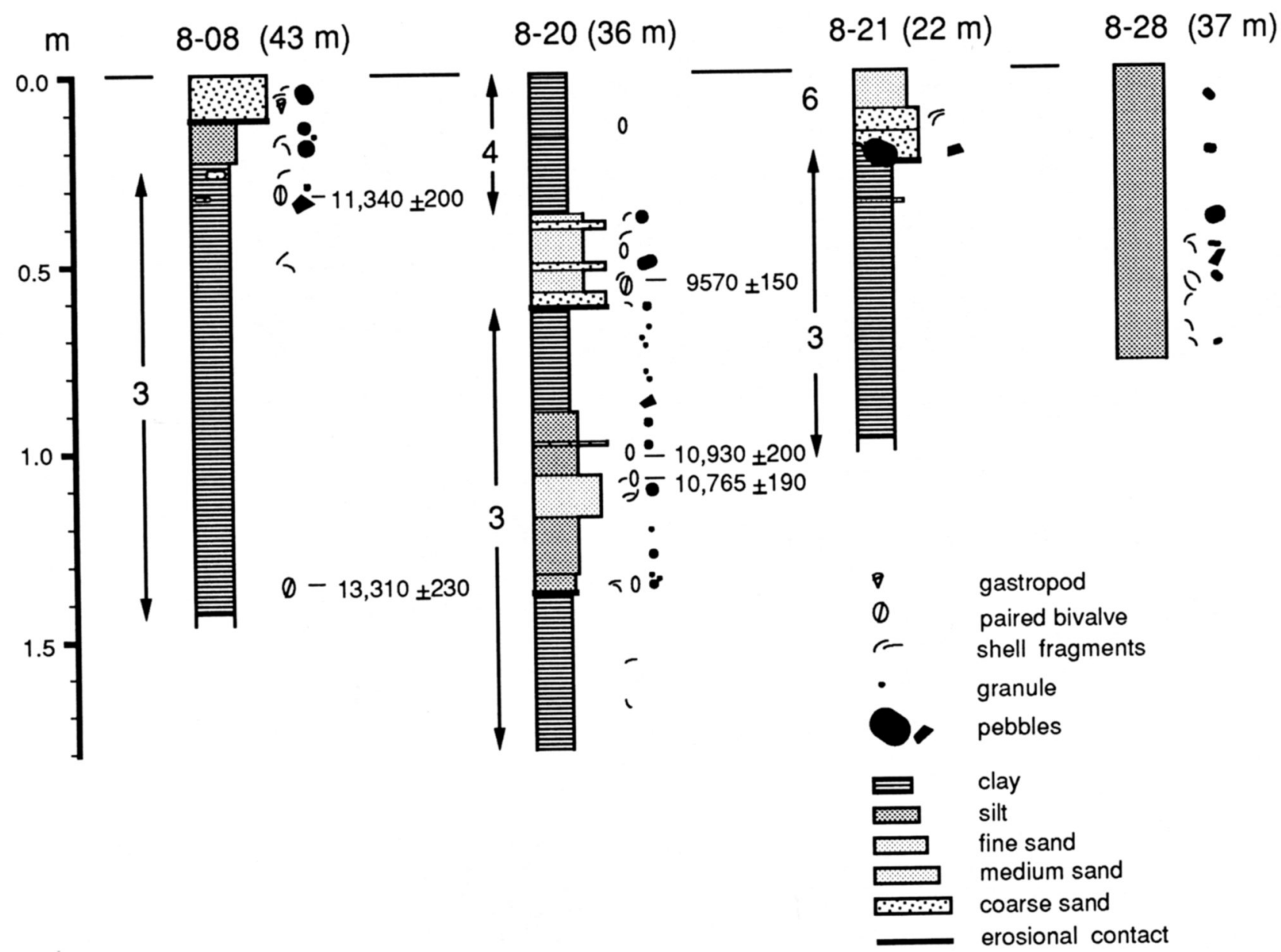

Fig. 12. Lithological logs for cores 8-08, 8-28, 8-20, and 8-21 (see Figs. 2 and 3 for locations). Equivalent acoustic units shown where appropriate.

abrupt lower contact of the sand is a grey-brown unit of mud, faintly laminated, with minor sand and a few fine pebbles and granules. This unit is $0.28 \mathrm{~m}$ thick and extends to $0.90 \mathrm{~m}$ down-core. It is underlain by $0.48 \mathrm{~m}$ of interbedded mud and sand. The upper $0.17 \mathrm{~m}$ and lower $0.15 \mathrm{~m}$ of this unit consist of dark grey to grey-brown silt and clay with a few granules and fine pebbles, including shattered clasts of red and black shale and a clast of gypsum, but no ophiolite material. The intervening $0.11 \mathrm{~m}$ of fine to coarse pebbly sand includes a red shale fragment. The lowermost unit in core 8-20, extending from $1.38 \mathrm{~m}$ down-core to the base, is a dark grey silty clay with occasional silt and sand partings. This mud is mottled and very faintly laminated.

Shell fragments were found in all parts of this core, except the brown mud between 0.62 and $0.90 \mathrm{~m}$ (Fig. 12). Radiocarbon ages were determined on complete bivalve specimens from three units in this core. A large specimen of Spisula polynyma (Stimpson) taken from fine sand at about $0.55 \mathrm{~m}$ down-core yielded a conventional radiocarbon age of $9570 \pm 150$ years B.P. (GSC-4724; Table 2). AMS determinations on a specimen of Astarte undata Gould at $1.02 \mathrm{~m}$ and a combined sample of $A$. undat $a$ and Nuculana pernula (Müller) at $1.08 \mathrm{~m}$ gave adjusted ages of $10,930 \pm 200$ and $10,765 \pm$
190 radiocarbon years B.P., respectively (Beta-88064/ETH5043 and Beta-88062/ETH-5041; Table 2).

The interbedded mud and sand below $0.62 \mathrm{~m}$ in this core are interpreted as paraglacial marine sediments corresponding to acoustic unit 3 . The pebbles within this unit are angular and assumed to be ice-rafted. The fine-coarse sand unit with subrounded pebbles overlying this unit, with an erosional base at $0.62 \mathrm{~m}$ down-core, is no older than about $9.7 \mathrm{ka}$. It is interpreted to represent shoreface reworking of sand at the postglacial lowstand of relative sea level. In this sense it may correspond to an early Holocene regressive equivalent of acoustic unit $6 \mathrm{a}$. The overlying $0.37 \mathrm{~m}$ of silty clay is interpreted as Holocene basin mud equivalent to acoustic unit 4.

\section{Core 8-21}

This core was taken in $22 \mathrm{~m}$ water depth, about $900 \mathrm{~m}$ landward of the location of core 8-20 (Figs. 3, 5). Core 8-21 is $1.00 \mathrm{~m}$ long and consists of an upper sand unit with an erosional and partially loaded base, overlying interlaminated clay and fine-medium sand. The upper coarse unit is a dark grey-brown, silty, fine to medium sand, grading to sand and 
gravel at the base. It contains a subangular pebble of gneiss in addition to several well-rounded fine pebbles. The underlying unit is composed of interlaminated red to red-grey clay and dark grey fine to medium sand. Shell fragments are present in the upper sand unit but are not observed in the lower clay and sand.

The sand and gravel at the top of core 8-21 is interpreted as a post-transgressive veneer developed following the earlyHolocene lowstand of relative sea level at this location. The underlying interlaminated clay and sand unit is interpreted to represent sediments from the lower to middle part of the glacial and paraglacial marine sequence, corresponding to acoustic unit 3 . The glacimarine deposits are considered to have been truncated by coastal and subaerial erosion during the lowstand at this location (Fig. 5).

\section{Core 8-28}

This core was collected in $37 \mathrm{~m}$ water depth northwest of Bluff Head, in the narrow basin north of the East Bay sill (Fig. 2). The core is $0.76 \mathrm{~m}$ long and consists exclusively of very dark grey silty fine sand with scattered pebbles and shell fragments (Fig. 12). This material is interpreted to represent reworking and winnowing of underlying glacimarine deposits of acoustic unit 3 (see fig. 6 of Forbes and Shaw, 1989).

\section{Other Supporting Data}

\section{Submerged deltas and shoreface in St. George's Bay}

Submerged deltaic sequences graded to about $-25 \mathrm{~m}$ are present off Stephenville Crossing (fig. 10 of Shaw and Forbes, 1990b), buried under coastal barrier deposits off Flat Bay Brook (fig. 9 of Shaw and Forbes, 1992), and off Romaines Brook between Port au Port and Stephenville (Fig. 1). These relict deltas suggest a lowstand within the inner bay at the same level as the terraces in Port au Port Bay. The depth and stratigraphy of the St. George's Bay sill are therefore critical to the question of the postglacial sea-level minimum in the area.

A well-defined erosional shore terrace at about $-25 \mathrm{~m}$ is present off Bank Head (Figs. 13, 14), buried under sediments of presumed Holocene age that form the present sill. This terrace truncates unit 3 sediments in a manner similar to that observed south of Two Guts Pond in Port au Port Bay (Fig. 5). It is associated with a wedge of sediment extending seaward from the limit of truncation, overlying the upper part of unit 3 (Fig. 13). Although the seismic profile is poorly defined seaward of this depositional wedge, we interpret it as evidence for a deeper sill at the time of the postglacial lowstand. While the present maximum depth of the sill is about $27 \mathrm{~m}$, suggesting the possibility that delta terraces in the inner bay may have been sill-limited, our interpretation of the shallow seismic records suggests that the original sill was closer to $35 \mathrm{~m}$ or deeper and did not control the level of lowstand deltas.

We interpret the lower part of unit 6 offshore from Bank
Head to be spit platform or tidal inlet deposits that accumulated in the passage between Bank Head and an extensive subaerial peninsula covering most of the sill to the north (Shaw and Forbes, 1992). Landward-dipping reflections offshore from the relict shore terrace (Fig. 13) are interpreted as recurve or washover deposits of a Flat Island precursor spit (Shaw and Forbes, 1992) that developed under rising relative sea level following the lowstand. The seismic records (fig. 11 of Shaw and Forbes, 1992) show barrier-platform and spillover fronts converging toward the centre of a deeper passage at a site just a few hundred metres to the east of the profile in Figure 13. We propose that the channel-like reflection pattern in the area of the present sill $(\rightarrow \leftarrow$ in Fig. 13) represents the culmination of this convergence process, filling in the narrowest part of the passage between outer St. George's Bay and the inner basins (Fig. 14).

\section{Coastal peat section at Two Guts Pond}

A $2 \mathrm{~m}$ thick exposure of peat was measured and sampled along the south shore of Two Guts Pond (Fig. 3, site marked 16). The section rested on 0.1 to $0.2 \mathrm{~m}$ of clay over red shale. The base of the peat overlying the clay was $0.1 \mathrm{~m}$ above mean water level. The section consisted of $0.1 \mathrm{~m}$ of grass and sedge peat overlain by $0.3 \mathrm{~m}$ of wood peat and $0.6 \mathrm{~m}$ of Ericaceous peat with $0.8 \mathrm{~m}$ of Sphagnum peat at the top of the section. Conventional radiocarbon age determinations were obtained for three samples from this section. These ranged from $9020 \pm 100$ years B.P. (GSC-4733) at the base of the peat to $4590 \pm 180$ years B.P. (Beta-36168) at the base of the Ericaceous unit and $2890 \pm 140$ years B.P. (Beta-36167) at the base of the Sphagnum (Table 2). The accumulation rates implied by these dates are $0.35 \mathrm{~m} \mathrm{ka}^{-1}$ for the Ericaceous peat and $0.28 \mathrm{~m} \mathrm{ka}^{-1}$ for the Sphagnum. The lowermost grasssedge and woody peat accumulated much more slowly and a hiatus in peat growth may have occurred during the formation of these units. The age of $9.0 \mathrm{ka}$ for the base of the peat corroborates published evidence that relative sea level had fallen below present by that time (Brookes et al., 1985; Grant, 1987).

\section{Palaeoenvironmental Reconstruction}

\section{Style and chronology of deglaciation}

The sedimentary record in Port au Port Bay, as in St. George's Bay to the south (Shaw and Forbes, 1990b, 1992), is generally consistent with land-based interpretations of Late Wisconsinan glaciation and postglacial events in the area (e.g., Brookes, 1974, 1987; Grant, 1989a, 1991). Acoustically unstratified deposits interpreted in part as glacial till and correlated with the St. George's River Drift (MacClintock and Twenhofel, 1940) form the base of the Quaternary section in both bays. Other parts of the marine record include partially buried tunnel valleys and a thick morainal ridge in St. George's Bay (Shaw and Forbes, 1990b), proglacial sand and gravel and draped glacimarine sediments of widely 


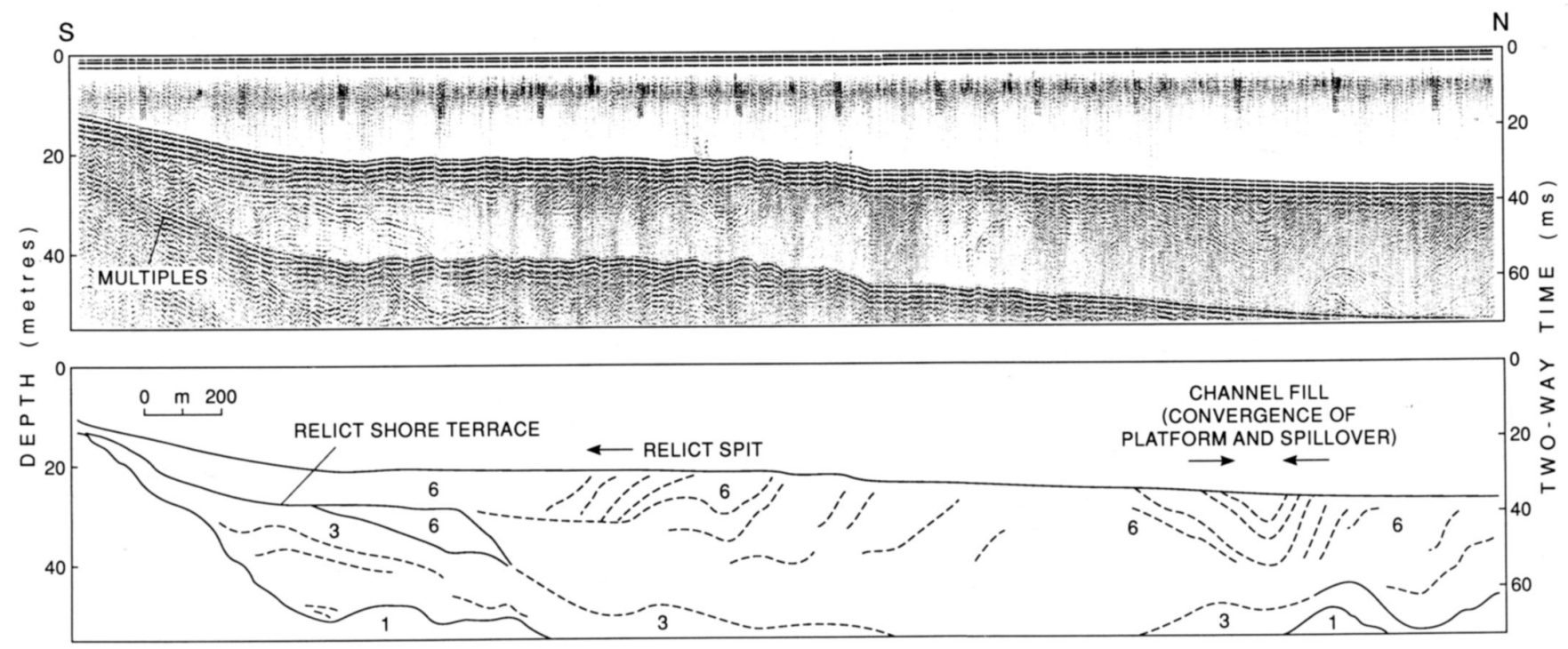

Fig. 13. Surface-tow sparker profile along shore-normal transect off Bank Head, St. George's Bay (see Fig. 14 for location). Record shows convergent transgressive infill $(\rightarrow \leftarrow)$ on the sill (see text), erosional shore terrace at about $-25 \mathrm{~m}$, and landward-prograded units of coastal spit that developed to seaward.

varying thickness in both bays (Fig. 9; Shaw and Forbes, 1990b), and a variety of postglacial littoral and basin deposits.

We envisage Late Wisconsinan ice filling St. George's and Port au Port bays from the east, as suggested by Brookes (1974) and Grant (1987), with divergent ice flow around the Lewis Hills nunatak (Fig. 1). Ice flowing to the north of the nunatak may have expanded southward to meet the southern lobe in the area off Bluff Head. This is the area containing the thickest accumulation of unit 1 in Port au Port Bay (Fig. 7), with seismic evidence suggesting stacked ice-contact deposits (Fig. 6). The ice in the bay is believed to have receded to the vicinity of the present eastern shore of Port au Port Bay by $13.7 \mathrm{ka}$, the time of the earliest ${ }^{14} \mathrm{C}$-dated marine shells in raised glacimarine deposits onshore (Table 1 ). This recession may have occurred largely by calving of a tidewater ice-front, as interpreted also for initial ice recession in St. George's Bay (Brookes, 1970; Grant in Blake, 1988; Shaw and Forbes, 1990b). Stratified sand and gravel associated with acoustic unit 2 may have been deposited subglacially or as subaqueous outwash (cf. Rust and Romanelli, 1975). Within Port au Port Bay, this appears to have been largely confined to the eastern part of the bay.

Following marine incursion with relative sea levels up to at least $44 \mathrm{~m}$ above present sea level (Brookes, 1969), a renewed glacial advance moved southward across the eastern part of the Port au Port Peninsula (Brookes, 1970; Fig. 1). This was confirmed by Grant (in Blake, 1988) from evidence of till overlying deformed marine silt containing Macoma sp. and Hiatella arctica with a radiocarbon age of $13,300 \pm 120$ years B.P. (GSC-4346; Table 1). It is not clear whether this ice movement was associated with the Robinsons Head readvance, for which various dates ranging from about $12.6 \mathrm{ka}$ (Brookes, 1977b) to older than $13.1 \mathrm{ka}$ (Grant, 1987) have been proposed. There is no evidence that northern East Bay (the area of core 8-08, Fig. 3) was overrun by ice after $13.3 \mathrm{ka}$.

The cores obtained in Port au Port Bay provide a preliminary radiocarbon chronology for marine sedimentation in these coastal basins. The earliest conformably-stratified deposits of unit 3, interpreted as glacimarine, are believed to be much older than $13.3 \mathrm{ka}$, based on the ${ }^{14} \mathrm{C}$ age of $13,310 \pm$ 230 years (Beta-88061/ETH-5040; Table 2; Fig. 12) on a specimen of Portlandia arctica from at least $6 \mathrm{~m}$ above the base of the unit (Fig. 8). Although the age of 11,340 \pm 200 radiocarbon years (Beta-88063/ETH-5042; Table 2) for a specimen of Astarte undata about $1 \mathrm{~m}$ higher in the core (Fig. 12) suggests a sedimentation rate of between 0.43 and $0.67 \mathrm{~m}$ $\mathrm{ka}^{-1}$, initial sedimentation near the base of unit 3 must have been much more rapid. It is reasonable to conclude that glacimarine sediments of unit 3 had begun to accumulate within the bay prior to the oldest late-glacial raised marine deposits onshore (before $13.7 \mathrm{ka}$; Table 1). Indeed the generally conformable nature of the boundary between units 2 and 3 (e.g., Fig. 8) suggests a gradational contact, as would be expected if unit 2 deposits represent coarse-grained subaqueous outwash fans that grade upward into finer density underflow and suspension fallout deposits (cf. Sharpe, 1988; Sharpe et al., 1992).

\section{Relative sea-level changes}

The relative sea-level curve in Figure 15 incorporates previously published data and new information on the Holocene lowstand presented in this paper. It shows initially rapid emergence attributed to glacio-isostatic rebound, with relative sea level falling from present elevations of about $44 \mathrm{~m}$ ca. $13.7 \mathrm{ka}$ to below $20 \mathrm{~m}$ by $13.0 \mathrm{ka}$. Small and poorly developed beach ridges at about $30 \mathrm{~m}$ present elevation southwest of 


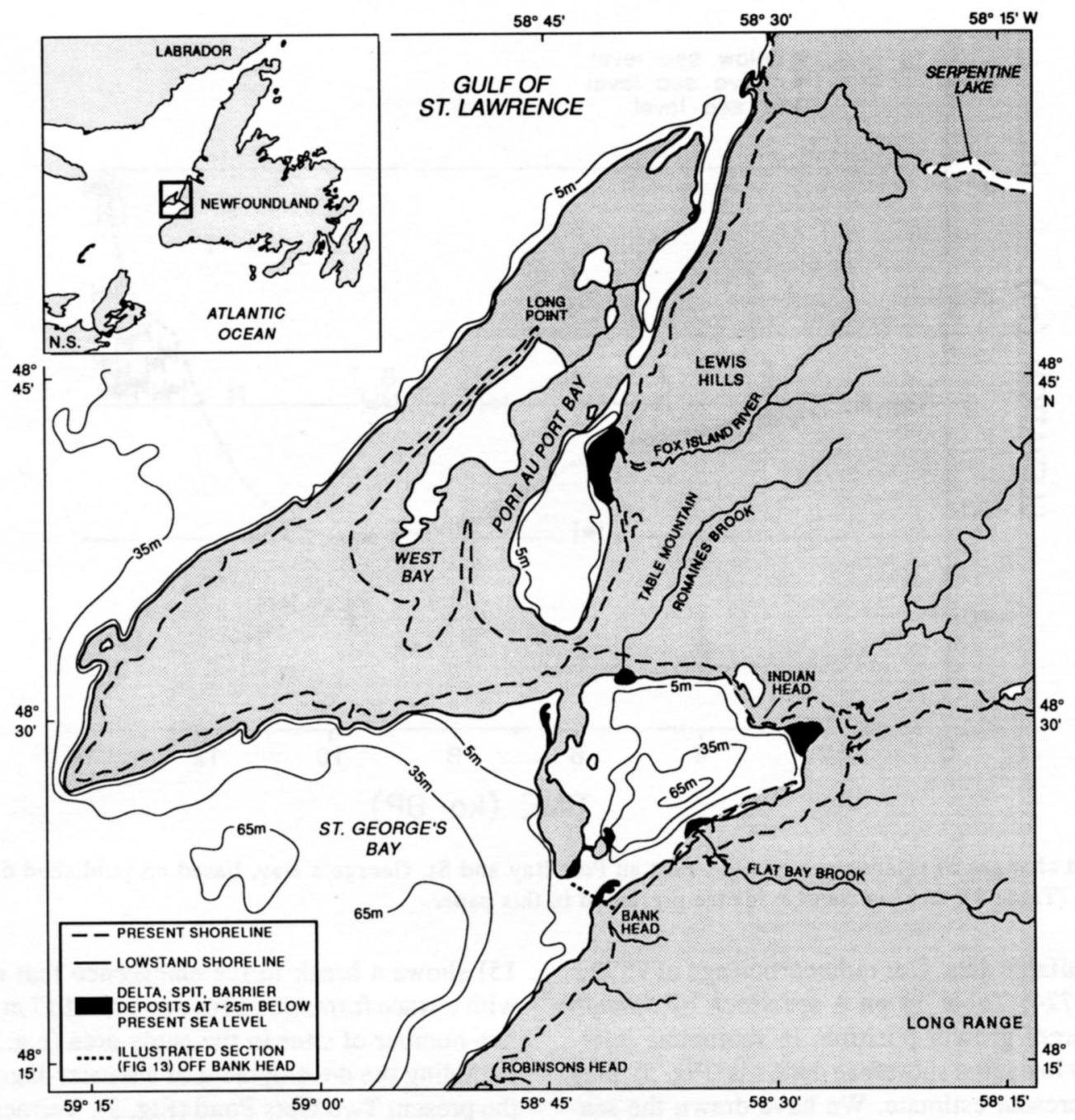

Fig. 14. Interpretation of the Holocene lowstand shoreline, showing inner St. George's Bay enclosed by a prominent peninsula on the present sill. Profile in Figure 13 extends from Bank Head northwest across former St. George's Bay entrance channel and critical part of sill. Note possible estuarine or lacustrine nature of lowstand water body in East Bay basin.

West Bay (Brookes, 1974) are among the very few expressions of early shoreline development in the area. Our reference to a relative sea level below $20 \mathrm{~m}$ is based on a ${ }^{14} \mathrm{C}$ age of 13,000 \pm 110 years (GSC-4584; Grant in McNeely and McCuaig, 1991; Table 1) on Macoma sp. and Mya truncata in a pebble gravel veneer overlying silty clay at $14 \mathrm{~m}$ above present sea level near Piccadilly Bay. This was interpreted by Grant (op. cit.) as a "near-littoral" deposit.

Grant (1987) reported ${ }^{14} \mathrm{C}$ ages of $12,700 \pm 110$ and $11,500 \pm 100$ years B.P. (GSC-4017 and GSC-4291; Table 1) on plant material from freshwater pond sediments 2 to $3 \mathrm{~m}$ above present sea level in a kettle depression near the mouth of Romaines River. On this basis, he proposed that relative sea level fell below present by $12.7 \mathrm{ka}$ (fig. 68 of Grant, 1987). We have examined the section in the field and believe that the plant detritus of GSC-4017 is likely to have been reworked from higher ground. Combining this observation with published interpretations of two younger marine shell samples collected at higher elevation (GSC-2295 and GSC2496; Brookes in Lowdon and Blake, 1978; Table 1), this suggests that emergence at present sea level may have been delayed by several hundred years beyond the date suggested by Grant (1987). Brookes (1977b) interpreted an age of $12,600 \pm 140$ years B.P. (GSC-2295), on Mya truncata fragments from sand interbedded in kame gravels $10 \mathrm{~m}$ above sea level, as relating to formation of the Robinsons Head moraine during a terrace-forming stillstand of relative sea level approximately $30 \mathrm{~m}$ above present. We find this difficult to reconcile with the near-littoral interpretation of the Piccadilly Bay gravel (GSC-4584), which would then have been deposited in a water depth of more than $16 \mathrm{~m}$ in a relatively sheltered setting.

We have therefore taken the emergence curve to be constrained as follows: upward only a few metres by GSC$4584,-2295$, and -2496 ; downward by the age of $11,500 \pm 100$ years B.P. (GSC-4291) on plant debris slightly higher in the Romaines section (Grant, 1987). Our representation (Fig. 15) suggests a marked reduction in the rate of emergence after 13 $\mathrm{ka}$, culminating at about $14 \mathrm{~m}$ above present sea level. This was followed by a return to rapid emergence and another deceleration to the sea-level minimum at about $-25 \mathrm{~m}$.

The timing of the Holocene lowstand is poorly con- 


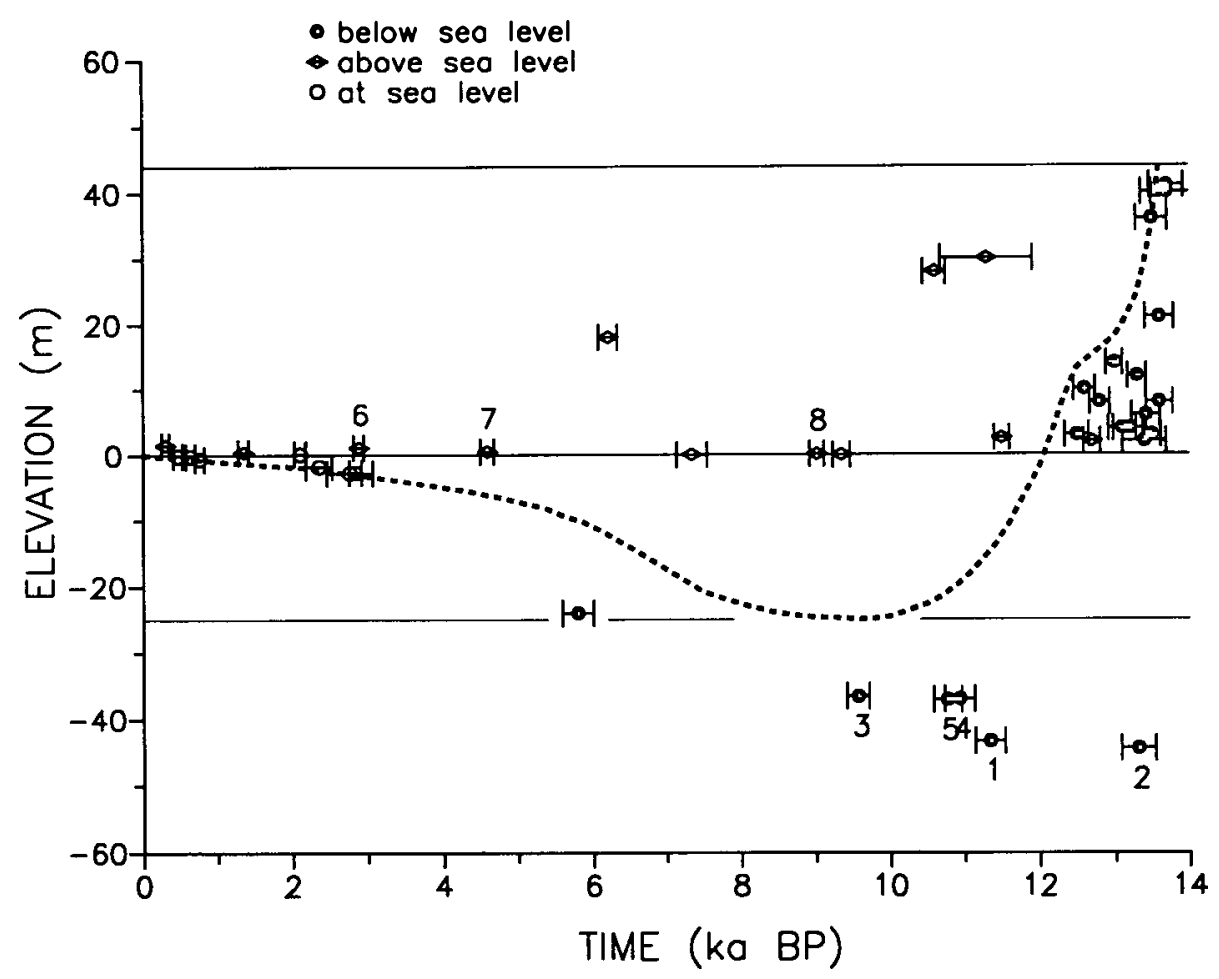

Fig. 15. Postglacial changes of relative sea level in Port au Port Bay and St. George's Bay, based on published data (Table 1), new radiocarbon results (Table 2 ), and lowstand evidence presented in this paper.

strained by the available data. Our radiocarbon age of $9570 \pm$ 150 B.P. (GSC-4724; Table 1) on a specimen of Spisula polynyma in apparent growth position, in sediments interpreted to represent lowstand shoreface deposits (Fig. 5), may provide the best present estimate. We have drawn the sealevel curve (Fig. 15) to reflect this interpretation. The age of $5800 \pm 210$ years B.P. (GSC-1203; Table 1) for shell fragments from a present water depth of about $24 \mathrm{~m}$ in West Bay was at one time thought to represent the Holocene lowstand (Shearer in Lowdon et al., 1971; Brookes et al., 1985). Instead we suggest that a lake may have existed in the West Bay basin for a few thousand years during the early Holocene, when relative sea level was below the elevation of the West Bay sill (Fig. 14). It is plausible to suggest that GSC1203 may represent the re-establishment of marine conditions in West Bay, implying that relative sea level had risen above $-14 \mathrm{~m}$ by $5.8 \mathrm{ka}$ (Fig. 15).

\section{Discussion}

The evidence presented here for the depth and timing of the Holocene lowstand pertains to southern Port au Port Bay and its immediate vicinity only. The regional variation of the postglacial marine limit on the west coast of Newfoundland, from $120 \mathrm{~m}$ in the north (Grant, 1972) to $44 \mathrm{~m}$ in the study area (Brookes et al., 1985) and approximately $0 \mathrm{~m}$ at the southwest corner of the island (Flint, 1940), implies a suite of spatially autocorrelated but widely varying sea-level curves for the west coast of the island (fig. 5.16 of Grant, 1989a).

The relative sea-level curve proposed in this paper (Fig.
15) shows a break in the emergence that can be correlated with terrace formation between 14 and $17 \mathrm{~m}$ present elevation at a number of sites in the study area (e.g., Brookes, 1974), including the development of a barrier-lagoon system above the present Two Guts Pond (Fig. 3). Terraces have also been identified at other levels, in particular a prominent feature at about $27 \mathrm{~m}$ elevation, correlated with the Robinsons Head readvance (Brookes, 1974, 1977b). This and other terraces could be accommodated by additional kinks in the emergence curve (it is possible that the curve should be drawn higher than we have shown in Fig. 15). Alternatively, terrace development could result in part from varying climatic conditions, with more open water and a more energetic wave climate at particular times during the regression.

Because of the long time scale associated with isostatic adjustments, short-term variations in the emergence rate may be most readily explicable in terms of changing rates of eustatic sea-level rise. If the latter were to equal the rate of uplift at any time, a stillstand would result. Fairbanks (1989) has developed a 17 ka glacio-eustatic sea-level curve from radiocarbon age determinations on submerged reef-crest corals off Barbados. This indicates two intervals of enhanced meltwater discharge to the global ocean. The first culminated in a sea-level rise of $24 \mathrm{~m} \mathrm{ka}^{-1}$ prior to $12.0 \mathrm{ka}$, followed by a minimum during the early part of the Younger Dryas interval, from 11.0 to $10.5 \mathrm{ka}$. The emergence curve for Port au Port Bay (as plotted in Fig. 15) is approximately 500 years out of phase with the Barbados record. The second meltwater pulse identified by Fairbanks (1989) was centred on $9.5 \mathrm{ka}$, correlating well with our estimate of the lowstand date in the Port 
au Port Bay area. Our intepretation of the geological and radiocarbon data for the study area suggests that the emergence curve could be delayed to match the coral evidence from Barbados. It is also conceivable that a deceleration occurred in the vicinity of the $27 \mathrm{~m}$ terrace level, in addition to (or instead of) the break we have plotted at 14 to $16 \mathrm{~m}$ (Fig. 15 ), but this would be more difficult to explain in relation to the eustatic record.

Our present interpretation of the Holocene sea-level history in Port au Port Bay suggests a rather prolonged lowstand, with relative sea level below $24 \mathrm{~m}$ present water depth for about 1800 years. During this time, Fox Island River discharged sediments into a severely constricted basin southeast of Fox Island (Figs. 3, 14). The restricted fetch and limited wave energy, particularly from the north, would have severely diminished the rate of longshore sediment dispersal to the south, promoting development of the extensive lowstand delta platform (Fig. 3). It is not clear whether the lowstand water body in East Bay became fully lacustrine or remained estuarine, but significant tidal currents may have developed in the narrows over the basin sill to the north before and after the lowstand. Constricted currents, enhanced by delta progradation, may have been responsible at least in part for the deep depression, down to $60 \mathrm{~m}$ present water depth (the deepest point in East Bay), fronting the relict lowstand delta (Fig. 3). This may account for the removal of the upper part of unit 3 in that area (Fig. 8).

The thickness of postglacial mud of unit 4 in Port au Port Bay varies greatly from basin to basin. This unit is thickest in East Bay, thinner in West Bay, and largely absent from "Fox Basin" (and possibly "Serpentine Basin") to the north. This unit may be derived in part from reworking of glacimarine deposits, but its distribution is consistent with a fluvial supply from Fox Island River as the primary source. Existing models of paraglacial sediment production (Church and Ryder, 1972; Church and Slaymaker, 1989; Forbes and Taylor, 1987) suggest that this supply is likely to have been at a maximum during the first few thousand years following deglaciation. The implication is that fine sediment discharged from Fox Island River was trapped primarily in East Bay, that its dispersal to West Bay occurred primarily before the Holocene lowstand of relative sea level (before West Bay was cut off from external sources of supply), and that circulation in the bay favoured southward and westward transport.

Understanding the timing of paraglacial sediment supply from Fox Island River is also important for the interpretation of coarse sediment dispersal and the distribution of chromite placer deposits in the bay. The extent and early postglacial age of the Fox Island River fan suggest the possibility of early reworking of the fan margin by waves along its outer margin (at relative sea levels higher than present), leading to the establishment of a coastal barrier complex south of the fan, at about $15 \mathrm{~m}$ elevation landward of Two Guts Pond (Fig. 3; also recognized by Grant, 1991). Our interpretation of this feature from aerial photographs requires further investigation on the ground, but it appears to represent a substantial littoral sediment accumulation that developed within about 2 ka following deglaciation. Significant discharge of fluvial sediment, augmented by downcutting into and reworking of earlier fan deposits, is believed to have continued to the early Holocene lowstand, culminating in the growth of the large submerged delta complex. Although northward transport may have been greater at higher relative sea levels (when the Port au Port isthmus was flooded and a free connection existed with St. George's Bay), the present pattern of southward longshore transport is presumed to have continued at varying rates during the regression and subsequent Holocene transgression. This led to the development of littoral deposits at various levels in the coastal compartment between Fox Island River and Black Point, including the present-day barrier at Two Guts Pond, with its extensive amalgamated flood-tidal delta and washover deposits.

These observations suggest that sand derived from Fox Island River may be present in the East Bay area in relict littoral deposits south of the present river mouth: (1) above present sea level landward of Two Guts Pond; (2) at present water depths down to $25 \mathrm{~m}$ in submerged shoreline facies (and possibly as deep as $35 \mathrm{~m}$ or more in shoreface deposits such as those encountered in core 8-20) between Fox Island River and Black Point; and (3) in modern littoral sediments along the margin of the fan and south along the coast in the Two Guts Pond embayment. These observations are consistent with early results of placer mineral exploration in the area (Corney, 1992; Emory-Moore et al., 1992). Significant volumes of sand are also present in the relict deltaic deposits (predominantly foreset facies) below present sea level off Fox Island River and in sediments of unit 6 deposited on top of the lowstand delta terraces during the Holocene transgression.

\section{Conclusions}

(1) Port au Port Bay contains a spatially variable suite of Late Quaternary deposits resulting from glaciation, ice-wasting, and postglacial sediment supply from rivers draining into the bay. Sediment distribution and facies characteristics reflect the locations and types of sediment sources and dispersal processes in relation to water depth, basin configuration, postglacial sea-level fluctuations, and other factors. Total sediment thickness is greatest $(>50 \mathrm{~m})$ in East Bay, reflecting glacimarine sediment supply from the south and east and the proximity of the dominant fluvial source, Fox Island River. (2) Six major acoustic units have been identified in shallowseismic records from Port au Port Bay. These are (i) glacial till or other acoustically unstratified ice-contact sediments, typically less than $10 \mathrm{~m}$ thick, but locally more than $20 \mathrm{~m}$ (possibly more than $40 \mathrm{~m}$ ); (ii) ice-contact or proximal stratified outwash deposits, typically thin and patchy; (iii) predominantly draped glacimarine and/or early paraglacial sandy silt and clay, at least $45 \mathrm{~m}$ thick in East Bay; (iv) postglacial marine and/or lacustrine mud, with maximum thickness in East Bay, containing shallow gas where mud thickness exceeds approximately $8 \mathrm{~m}$; (v) postglacial marine and/or lacustrine sand and gravel, including foreset and topset fa- 
cies, forming submerged terraces down to about $25 \mathrm{~m}$ below present sea level; (vi) mid- to late-Holocene deltaic and reworked transgressive deposits of sand and gravel, the latter occurring as shoreface wedges and thin $(\leq 8 \mathrm{~m})$ progradational flood-tidal and/or spillover packages.

(3) Much of the glacimarine sediment package was deposited rapidly during and shortly after recession of ice from Port au Port Bay, as indicated by a radiocarbon age of $13.3 \mathrm{ka}$ on shell material from this unit. Deposition of unit 3 continued until at least $10.8 \mathrm{ka}$. Theoretical considerations and sediment distribution both suggest that paraglacial sediment supply, including the contribution from Fox Island River, was highest in early postglacial time and diminished rapidly thereafter.

(4) Deltaic terraces, shore platforms, and other features in Port au Port Bay and adjacent St. George's Bay suggest that the postglacial minimum of relative sea level was approximately $25 \mathrm{~m}$ below present mean sea level. The age of the sealevel minimum is poorly constrained but appears to be early Holocene, probably about $9.5 \mathrm{ka}$. The present depth of the East Bay sill is about $25 \mathrm{~m}$, suggesting that there may have been a freshwater lake or brackish estuary in the bay at this time. A lake is presumed to have existed in West Bay until its sill, presently $14 \mathrm{~m}$ below sea level, was overtopped ca. $6 \mathrm{ka}$. (5) The nature and timing of sea-level fluctuations, fluvial sediment supply, and wave-driven dispersal and sorting processes, suggest that sand and placer minerals originating in the Fox Island River basin may be found above present sea level in littoral deposits landward of Two Guts Pond, below present sea level at depths down to $35 \mathrm{~m}$ between Fox Island River and Black Point, and in modern shoreface and littoral deposits in the same area.

\section{ACknowledgements}

It is a pleasure to acknowledge the efforts of Neil Langille (master), Enrique de Arcos (engineer), and Hugh Marryatt (cook and deckhand) of the research vessel Navicula for their contribution to our 1988 survey program in Port au Port Bay. We also wish to acknowledge the technical contributions of Don Locke (acoustics), Darrell Beaver (navigation), and Art Cosgrove, Ken Hale, and Francis Kelly (drafting). We are grateful to Kimberley Edwardson, Steve Solomon, Doug Grant, Vaughn Barrie, and Ian Brookes for careful and constructive reviews.

BARD, E. 1988. Correction of accelerator mass spectrometry ${ }^{14} \mathrm{C}$ ages measured in planktonic foraminifera: paleoceanographic implications. Paleoceanography, 3, pp. 635-645.

Bard, E., Hamelin, B., Fairbanks, R.G., and Zindler, A. 1990. Calibration of the ${ }^{14} \mathrm{C}$ timescale over the past 30,000 years using mass spectrometric U-Th ages from Barbados corals. Nature, 345, pp. 405-410.

Becker, B., Kromer, B., and Trimborn, P. 1991. A stableisotope tree-ring timescale of the Late Glacial/Holocene boundary. Nature, 353, pp. 647-649.

BLAKE, W., JR. 1986. Geological Survey of Canada radiocarbon dates XXV. Geological Survey of Canada, Paper 85-7, 32 p. 1988. Geological Survey of Canada radiocarbon dates
XXVII. Geological Survey of Canada, Paper 87-7, 100 p.

Brookes, I.A. 1969. Late-glacial marine overlap in western Newfoundland. Canadian Journal of Earth Sciences, 6, pp. 1397-1404.

1970. New evidence for an independent Wisconsin-age ice cap over Newfoundland. Canadian Journal of Earth Sciences, 7. pp. 1374-1382.

1974. Late-Wisconsin glaciation of southwest Newfoundland (with special reference to the Stephenville map-area). Geological Survey of Canada, Paper 73-40, 31 p.

- 1977a. Geomorphology and Quaternary geology of the Codroy Lowland and adjacent plateaus, southwest Newfoundland. Canadian Journal of Earth Sciences, 14, pp. 2101 -2120.

1977b. Radiocarbon age of Robinson's Head moraine, west Newfoundland, and its significance for postglacial sea level changes. Canadian Journal of Earth Sciences, 14, pp. 2121-2126.

1982. Ice marks in Newfoundland: a history of ideas. Géographie physique et Quaternaire, 36, pp. 139-163.

- 1987. Late Quaternary glaciation and sea-level change, southwest Newfoundland, Canada. In Geological Society of America, Centennial Field Guide Volume 5, Northeastern Section, pp. 445-450. Edited by D.C. Roy.

Brookes, I.A., Scotr, D.B., and MCANDrEws, J.H. 1985. Postglacial relative sea-level change, Port au Port area, west Newfoundland. Canadian Journal of Earth Sciences, 22, pp. 1039 1047.

ChURCH, M. and RYDER, J.M. 1972. Paraglacial sedimentation: a consideration of fluvial processes conditioned by glaciation. Geological Society of America Bulletin, 83, pp. 3059-3072.

Church, M. and Slaymaker, O. 1989. Disequilibrium of Holocene sediment yield in glaciated British Columbia. Nature, 337, pp. 452-454.

Coleman, A.P. 1926. The Pleistocene of Newfoundland. Journal of Geology, 34. pp. 193-223.

CoRney, R.E. 1992. A depositional model for chromite-bearing Quatemary sediments of Port au Port Bay, Newfoundland [abstract]. Geological Association of Canada-Mineralogical Association of Canada, Joint Annual Meeting, Wolfville, Nova Scotia. Abstracts Volume, 17, p. A20.

DALE, C.T. and HA WORTH, R.T. 1979. High resolution reflection seismology studies on Late Quaternary sediments of the northeast Newfoundland continental shelf. Geological Survey of Canada, Paper 79-1B, pp. 357-364.

DALY, R.A. 1921. Postglacial warping of Newfoundland and Nova Scotia. American Journal of Science, 5th series, 201, pp. 381-391.

Dunsworth, S., Calon, T., and Malpas, J. 1986. Structural and magmatic controls on the internal geometry of the plutonic complex and its chromite occurrences in the Bay of Islands Ophiolite, Newfoundland. Geological Survey of Canada, Paper 86-1B, pp. 471-482.

EDDY, B.G. 1989. Interpretation of shallow seismic reflection and sidescan sonar data in Port au Port Bay, Newfoundland. Geological Survey of Canada, Open File 2102, 27 p. and 8 maps.

Emory-Moore, M., Solomon, S., and Dunsmore, D. 1988. Placer potential of Fox Island River and east-central Port au Port Bay: a preliminary assessment. Newfoundland Department of Mines and Energy, Mineral Development Division, Paper 88-1, pp. 343-357.

1989. Chromitiferous placer accumulations, Fox Island 
River and east-central Port au Port Bay, Newfoundland: a preliminary examination. Marine Mining, 8, pp. 139-154.

Emory-Moore, M., Scott, W.J., Davis, L., and Solomon, S. 1992. Detrital chromite concentrations, nearshore Port au Port Bay, Newfoundland. Atlantic Geology, 28, pp. 233-241.

Fader, G.B., King, L.H., and Josenhans, H.W. 1982. Surficial geology of the Laurentian Channel and the western Grand Banks of Newfoundland. Geological Survey of Canada, Paper $81-22,37 \mathrm{p}$.

FAIRBANKS, R.G. 1989. A 17,000-year glacio-eustatic sea level record: influence of glacial melting rates on the Younger Dryas event and deep-ocean circulation. Nature, 342, pp. 637-642.

FaIRChILD, H.L. 1918. Postglacial uplift of northeastem North America. Geological Society of America Bulletin. 29, pp. 187-238.

FLINT, R.F. 1940. Late Quaternary changes of level in western and southern Newfoundland. Geological Society of America Bulletin, 51, pp. 1757-1780.

Forbes, D.L. 1984. Coastal geomorphology and sediments of Newfoundland. Geological Survey of Canada, Paper 84-1B, pp. 11-24.

Forbes, D.L. and Shaw, J. 1989. Cruise report 88018(E), Navicula operations in southwest Newfoundland coastal waters: Port au Port Bay, St. George's Bay, La Poile Bay to Barasway Bay and adjacent inner shelf. Geological Survey of Canada, Open File 2041, 57 p.

Forbes, D.L. and TAYLOR, R.B. 1987. Coarse-grained beach sedimentation under paraglacial conditions, Canadian Atlantic coast. In Glaciated coasts. Edited by D.M. FitzGerald and P.S. Rosen. Academic Press, San Diego, pp. 51-86.

Forbes, D.L., TAYLOR, R.B., and ShAw, J. 1989. Shorelines and rising sea levels in eastern Canada. Episodes, 12, pp. 23-28.

Forbes, D.L., Boyd, R., and Shaw, J. 1991. Late Quatemary sedimentation and sea level changes on the inner Scotian Shelf. Continental Shelf Research, 11, pp. 1155-1179.

GilberT, G.K. 1885. The topographic features of lake shores. United States Geological Survey, Annual Reports, 5, pp. 69. 123.

1890. Lake Bonneville. United States Geological Survey, Monograph, 1, 438 p.

Grant, D.R. 1972. Postglacial emergence in northem Newfoundland. Geological Survey of Canada, Paper 72-1B, pp. 100102.

1977. Glacial style and ice limits, the Quaternary stratigraphic record, and changes of land and ocean level in the Atlantic Provinces, Canada. Géographie physique et Quaternaire, 31, pp. 247-260.

1980. Quaternary sea-level change in Atlantic Canada as an indication of crustal delevelling. In Earth rheology, isostasy and eustasy. Edited by N.-A. Mörner. Wiley-Interscience, pp. 201-214.

1987. Quaternary geology of Nova Scotia and Newfoundland. Guidebook, XIIth INQUA Congress, Field Excursion A-3/C-3. National Research Council Canada, Ottawa, 62 p.

- 1989a. Quaternary geology of the Atlantic Appalachian region of Canada. In Quaternary geology of Canada and Greenland. Edited by R.J. Fulton. Geological Survey of Canada, Geology of Canada 1 (also: The geology of North America, Geological Society of America, K-1), pp. 393-440.

1989b. Surficial geology, Sandy Lake - Bay of Islands, Newfoundland. Geological Survey of Canada, Map 1664A, scale 1:250 000 .

-1991. Surficial geology, Stephenville - Port aux Basques. Geological Survey of Canada, Map 1737A, scale 1:250 000.

HiLl, P.A. and Ruest, A.E. 1980. Heavy minerals and metals in Port au Port Bay, Newfoundland. Economic Geology, 46, pp. 961-970.

Jenner, K.A. and Shaw, J. 1992. Inner shelf Quaternary sediments off northeast Newfoundland. Geological Survey of Canada, Paper 92-1D, pp. 189-198.

Josenhans, H., Zevenhuizen, J., and Maclean, B. 1990. Preliminary seismostratigraphic interpretations from the Gulf of St. Lawrence. Geological Survey of Canada, Paper 90-1B, pp. 59-75.

KING, L.H. and FADER, G.B. 1986. Wisconsinan glaciation of the Atlantic continental shelf of southeast Canada. Geological Survey of Canada, Bulletin 363, 72 p.

Lowdon, J.A. 1985. The Geological Survey of Canada Radiocarbon Dating Laboratory. Geological Survey of Canada, Paper 84-24, 19 p.

Lowdon, J.A. and Blake, W., JR. 1968. Geological Survey of Canada radiocarbon dates VII. Radiocarbon, 10, pp. 207-245. 1970. Geological Survey of Canada radiocarbon dates IX. Radiocarbon, 12, pp. 46-86.

1975. Geological Survey of Canada radiocarbon dates XV. Geological Survey of Canada, Paper 75-7, 32 p.

1978. Geological Survey of Canada radiocarbon dates XVIII. Geological Survey of Canada, Paper 78-7, 20 p.

1980. Geological Survey of Canada radiocarbon dates XX. Geological Survey of Canada, Paper 80-7, 28 p.

Lowdon, J.A., Robertson, I.M., and Blake, W., JR. 1971. Geological Survey of Canada radiocarbon dates XI. Radiocarbon, 13, pp. 255-324.

MaCClintock, P. and Twenhofel, W.H. 1940. Wisconsin glaciation of Newfoundland. Geological Society of America Bulletin, 51, pp. 1729-1756.

Mangerud, J. and Gulliksen, S. 1975. Apparent radiocarbon ages of recent marine shells from Norway, Spitsbergen, and arctic Canada. Quaternary Research, 5, pp. 263-273.

McNeely, R. and McCuaig, S. 1991. Geological Survey of Canada radiocarbon dates XXIX. Geological Survey of Canada, Paper 89-7, 134 p.

Piper, D.J.W., Letson, J.R.J., DeIure, A.M., and Barrie, C.Q. 1983. Sediment accumulation in low-sedimentation, wavedominated, glaciated inlets. Sedimentary Geology, 36, pp. 195-215.

Postma, G. 1990. Depositional architecture and facies of river and fan deltas: a synthesis. International Association of Sedimentologists, Special Publication 10, pp. 13-27.

Quinlan, G. and Beaumont, C. 1981. A comparison of observed and theoretical postglacial relative sea level in Atlantic Canada. Canadian Journal of Earth Sciences, 18, pp. 1146-1163.

1982. The deglaciation of Atlantic Canada as reconstructed from the postglacial relative sea-level record. Canadian Journal of Earth Sciences, 19, pp. 2232-2246.

RILEY, G.C. 1962. Stephenville map-area, Newfoundland. Geological Survey of Canada, Memoir 323, 72 p.

Rust, B.R. 1977. Mass flow deposits in a Quaternary succession near Ottawa, Canada: diagnostic criteria for subaqueous outwash. Canadian Journal of Earth Sciences, 14, pp. 175 184.

Rust, B.R. and Romanelli, R. 1975. Late Quaternary subaqueous outwash deposits near Ottawa, Canada. In Glaciofluvial 
and glaciolacustrine sedimentation. Edited by A.V. Jopling and B.C. McDonald. Society of Economic Paleontologists and Mineralogists, Special Publication 23, pp. 177-192.

ShARPE, D.R. 1988. Glaciomarine fan deposition in the Champlain Sea. In The Late Quaternary development of the Champlain Sea basin. Edited by N.R. Gadd. Geological Association of Canada, Special Paper 35. pp. 63-82.

Sharpe, D.R., Pullan, S.E., and Warman, T. 1992. A basin analysis of the Wabigoon area of Lake Agassiz, a Quaternary clay basin in northwestern Ontario. Géographie physique et Quaternaire, 46, pp. 295-309.

Shaw, J. 1985. Subglacial and ice marginal environments. In Glacial sedimentary environments. Edited by G.M. Ashley, J. Shaw and N.D. Smith. Society of Economic Paleontologists and Mineralogists, Short Course 16, pp. 7-84.

Shaw, J. and Forbes, D.L. 1987. Coastal barrier and beach-ridge sedimentation in Newfoundland. In Proceedings, Canadian Coastal Conference 1987 (Québec). National Research Council Canada, Ottawa, pp. 437-454.

1990a. Short- and long-term relative sea-level trends in Atlantic Canada. In Proceedings, Canadian Coastal Conference (Kingston, Ontario). National Research Council Canada, Associate Committee on Shorelines, Ottawa, pp. 291305.

1990b. Late Quaternary sedimentation in St. George's Bay, southwest Newfoundland: acoustic stratigraphy and seabed deposits. Canadian Journal of Earth Sciences, 27, pp. 964-983.

1992. Barriers, barrier platforms, and spillover deposits in St. George's Bay, Newfoundland: paraglacial sedimentation on the flanks of a deep coastal basin. Marine Geology, 105, pp. 119-140.

Shaw, J., Taylor, R.B., and Forbes, D.L. 1990. Coarse clastic barriers in eastern Canada: patterns of glaciogenic sediment dispersal with rising sea levels. In Proceedings, Skagen Symposium (Skagen, Denmark). Journal of Coastal Research, Special Issue 9, pp. 160-200.

She ARER, J.M. 1970. Detailed grain size analysis of recent marine sediments and post-glacial history of Port au Port Bay,
Newfoundland. Unpublished M.Sc. dissertation, Memorial University of Newfoundland, St. John's, Newfoundland, 234 p.

1973. Bedrock and surficial geology of the northern Gulf of St. Lawrence as interpreted from continuous seismic reflection profiles. In Earth science symposium on offshore eastern Canada. Edited by P.J. Hood. Geological Survey of Canada, Paper 71-23, pp. 285-303.

Stockmal, G.S. and WAldron, J.W.F. 1992. Structure and tectonic setting of the Port au Port Peninsula, western Newfoundland: implications for Humber Zone tectonics and Acadian versus Taconian overthrust events [abstract]. Atlantic Geology, 28, p. 289.

Swinden, H.S. and Forbes, D.L. 1989. Geochemical analyses of bottom sediments in Port au Port Bay and St. George's Bay, western Newfoundland. Department of Mines and Energy, Geological Survey Branch, St. John's, Open File 12B/312, 12 p.

SyvitsKI, J.P.M. 1989. On the deposition of sediment within glacier-influenced fiords: oceanographic controls. Marine Geology, 85, pp. 301-329.

1992. Marine geology of Baie des Chaleurs. Géographie physique et Quaternaire, 46, pp. 331-348.

Syvitski, J.P.M. and PraEg, D.B. 1989. Quaternary sedimentation in the St. Lawrence Estuary and adjoining areas, eastem Canada: an overview based on high resolution seismo-stratigraphy. Géographie physique et Quaternaire, 43, pp. 291310.

Thors, K. and Boulton, G.S. 1991. Deltas, spits and littoral terraces associated with rising sea level: Late Quaternary examples from northern Iceland. Marine Geology, 98, pp. 99112.

Williams, H. 1985. Geology of the Stephenville map area, Newfoundland. Geological Survey of Canada, Map 1579A, scale 1:100 000 .

Williams, H. and Cawood, P.A. 1989. Geology, Humber Arm Allochthon, Newfoundland. Geological Survey of Canada, Map 1678A, scale 1:250 000. 